Espacio, Tiempo y Forma, Serie IV, H. Moderna, t. 10, 1997, págs. 53-98

\title{
Fiesta y alimentación en la España moderna: el banquete como imagen festiva de abundancia y refinamiento
}

\author{
María de los Ángeles Pérez Samper*
}

\section{RESUMEN}

El banquete es uno de los signos de fiesta por excelencia. Imagen de abundancia, refinamiento, placer y tradición, por una parte refleja el orden social establecido y por otra parte significa lo extraordinario, la ruptura de la rutina. Los ricos comen todavia más y mejor y los pobres

escapan al menos por un dia de la escasez y la limitación cotidianas. En

la España moderna, desde los grandes banquetes cortesanos, llenos de lujo y fantasia, hasta los más modestos banquetes de las cofradias, todos los grupos sociales, de los más altos a los más bajos, se manifiestan en sus fiestas alimentarias. El ritmo de la vida queda subrayado, por ejemplo, en los

siempre espléndidos banquetes de boda. El ritmo del año 10 marcan también múltiples celebraciones alimentarias, Navidad, Carnaval,

\section{ABSTRACT}

The banquet is, no doubt, one of the signs of feast par excellence. Image of abundance, refinement, pleasure and tradition, it reflects, on the one hand, the established social order and on the other means the extraordinary, the rupture of the daily rutine. The rich eat even more and better than usual and the poor avoid at least for one single day the shortage of food and the day to day limitations. In Early modern Spain, from the great court banquets, which were luxurious and full of fantasy, to the most humble guild banquets, the whole social groups, from the upper class to the lowest ones, manifest their social position in their food feasts. The everyday rate is usually emphasized, for instance, in the ever splendid wedding breakfasts. The year rate is also marked with a large number of food feasts, which are held at Christmas, Carnival and in our "fiestas mayores". The

\footnotetext{
* Departamento de Historia Moderna. Universidad de Barcelona.
} 
fiestas mayores. El banquete no es sólo realidad es también utopia y se

sueña en el imaginario colectivo como un ideal de vida en que la necesidad de comer para vivir se transforma en el placer de vivir para comer. banquet is not only nourishment but a performance as well. The banquet goes beyond reality, it is also utopia and the collective mentality dreams of it as an ideal of live in which the need to eat in order to survive turns into the pleasure of living to enjoy eating.

La fiesta se halla con mucha frecuencia asociada al hecho alimentario, una fiesta en la que no se coma, no se coma mucho y no se coma bien parece una fiesta incompleta. Sin un buen banquete algo falta en las celebraciones. A veces la alimentación ocupa el lugar central de la fiesta, otras veces sólo tiene un papel complementario, pero suele ser siempre importante. La misma diferenciación existente entre fiesta oficial y fiesta popular puede hacerse entre banquete oficial y banquete popular. Si la alimentación es un fenómeno cultural y siempre es utilizada como signo de diferenciación social, el banquete es un claro exponente de una sociedad y una cultura ${ }^{1}$. En el siglo xvIII el Diccionario de Autoridades de la Real

En la historiografía española son los medievalistas los que más se han ocupado del tema, vid., sobre todo, los importantes trabajos del máximo especialista español en historia de la alimentación, RIERA MELIS, Antoni, "Estructura social y sistemas alimentarios en la Cataluña bajomedieval» en Acta historica et archaeologica medievalia, 14-15. Barcelona, 1993-1994, págs. 193-217, y Senyors, monjos i pagesos: Alimentació $i$ identitat social als segles xil i xim. Barcelona, Institut d'Estudis Catalans, 1997, entre otros estudios del autor. Vid también entre las últimas aportaciones, por ejemplo, AuROER + TASSIS, Anna, «Un convit reial a la Barcelona del segle XV». ARGILES ALUJA, Caterina, "L'àpat, element de celebració d'un fet extraordinari, a la baixa edat mitjana". LALIENA CORBERA, Carlos, "Sicut ritum est in terra aragonensis: comidas rituales y formas de solidaridad campesina en el siglo $x \mid »$. ALcoy, Rosa, “Banquet, celebració i festa. Consideracions sobre el paper dels àpats en el retaule medieval", todos ellos en Ir Col loqui d História de l'Alimentació a la Corona d'Aragó. Edat Mitjana, vol. 2. Lleida, Institut d’Estudis Herdencs, 1995, y FALCON PÉREZ, Maria Isabel, “Banquetes en Aragón en la Baja Edad Media" en La Mediterrània, àrea de convergència de sistemes alimentaris (segles $v$-xvili), Palma de Mallorca, Institut d’Estudis Baleàrics, 1996, págs. 509-521.

En la historiografía extranjera la bibliografia sobre el tema es amplia y variada. Destacaremos algunos trabajos interesantes referidos a la época moderna. FOREST DIVONNE, Marie de la, y MaIllaRD, Isabelle, Festins de France. París, Herscher, 1987. VenARD, Marc, "La fraternité des banquets" en Pratiques et discours alimentaires a la renaissance. París, Maisonneuve et Larose. 1982, págs. 137-145. VECA, Alberto, “Images de la nourriture dans l'art moderne», especialmente el apartado "Banquets, buffets, tables dressées", en FLANURIN, Jean Louis, y MONTANARI, Massimo (directores), Histoire de l'alimentation. París, Fayard, 1996, págs. 709-713. PAscale, Barbara di, Banchetti Estensi. La spettacolarità del cibo alla corte di Ferrara nel Rinascimento. Imola, La Mandragora, 1995. DitLoN Bussi, Angela, "Una festa di nozze principesca e un banchetto umanistico" y Grieco, Allen J., “Menu, Banchetti e Tavole imbandite in Toscana", en Coquatur ponendo... Cultura della cucina e della tavola in Europa tra medioevo ed età moderna. Prato. Istituto Internazionale di Storia Economica, “Francesco Datini», 1996, págs. 311-324 y 371-396, respectivamente. Sabban, F. y Serventi, S., A tavola nel Rinascimento. Roma-Bari, Laterza, 1996. Wuson, Anne (ed.), Food and Society. "Banquetting Stuffe". Edimburgo, Edinbourgh University Press, 1991. Holme, Brian, Princely Feasts and Festivals. Londres, Thames and Houston, 1988. 
Fiesta y alimentación en la España moderna: el banquete como imagen festiva...

Academia definía así el banquete: “Comida, merienda o cena espléndida, regalada y abundante, de mucho aparato y diversidad de manjares, en que concurren muchos convidados."

El banquete iba siempre obligatoriamente asociado a la abundancia. Darse un banquete era, ante todo, comer mucho. Para las clases ricas era una manifestación de su poder y riqueza. Para las clases pobres significaba salir de la rutina, la escasez y el hambre y poder hartarse, aunque sólo fuera un día, muy de vez en cuando. Como diría un personaje del Quijote: "este dia no es de aquellos sobre quien tiene jurisdicción la hambre...» 2 ${ }^{2}$. Comer mucho tenía naturalmente sus riesgos. Los médicos no se cansaban de advertir contra semejantes excesos en el comer y el beber, pero la gente no hacía demasiado caso de sus sabios consejos. En el pecado llevaban la penitencia, pues las enfermedades acechaban a los que caían frecuentemente en las tentaciones de la gula. Luis Lobera de Ávila, médico del Emperador Carlos V, en su famosa obra Banquete de Nobles Caballeros, comenzaba por presentar el modelo de un abundante y selecto menú de banquete, tal como se estilaba a comienzos del siglo xvi en la corte imperial, pero advirtiendo de los riesgos que corría la salud de los que se dejaban llevar sin mesura por los placeres del gusto:

«En un buen banquete ha de haber muchas frutas de principio, y cosas de leche y queso y mucha diversidad de carnes, ansí como carnero, vaca, ternera, venado, cabrito, lechones y ansarones, etc. Muchas maneras de aves, ansi como faisanes, francolines, codornices, perdices, esternas, gallinas, pollos, pavos, etc. Liebres, conejos, gaçapos, etc. $Y$ todo de diversas maneras guisado con manteca y vino y vinagre; y todo género de salsas y pasteles, y todo género de pescados. Porque el banquete no se dice agora bueno si no entra en él pescado y carne, y para postre muchas maneras de frutas, ansí como de pasta y fritura, y toda especie de vino y toda suerte de cerveza, y beber "autant", que agora dicen. $Y$ así, desta manera, las personas que to usaren vivirán poco, y lo que vivieren será labor et dolor, no embargante lo que algunos dicen: que los han usado muchas veces y ningun daño han sentido, lo cual adelante daña, aunque de presente no se sienta" ${ }^{3}$.

Pero el banquete no era sólo abundancia, suponía también frecuentemente refinamiento. Se trataba de comer mucho y bien. La idea de comer bien, sin embargo, no era igual para todos. Para los pobres, comer bien

\footnotetext{
Cervantes, Miguel de, Don Quijote de la Mancha, II Parte,Cap. XX: "Donde se cuentan las bodas de Camacho el rico con el suceso de Basilio el pobre".

Lopez PINEIRO, José M." E , Vanquete de Nobles Cavalleros (1530), de Luis Lobera de Ávila y la higiene individual del siglo xvi. Madrid, Ministerio de Sanidad y Consumo, 1991, incluye ed. facsímil, vid, págs. 17-18.
} 
era sobre todo comer mucho. Pero como la capacidad de comer tiene un límite, para los ricos era necesario pasar de comer mucho a comer bien, en el sentido de comer refinadamente, para utilizar el banquete como signo de distinción social. Comer bien era así comer productos caros, raros, poco comunes, que no estuvieran al alcance de todos o que no pudieran comerse todos los días. Productos preparados de manera laboriosa, complicada, que necesitaran mucha gente, mucho tiempo, conocimientos sólo al alcance de unos pocos, instrumentos, utensilios o lugares de elaboración especiales. Refinamiento era también comer de acuerdo con la moda, con la novedad. La innovación culinaria era un destacado medio de distinción. Otro elemento importante del refinamiento era la variedad, debía haber mucho para poder elegir, para tener la seguridad de que cada comensal encontraría sus productos y platos preferidos y podría satisfacer su capricho. La libertad de elección también era un lujo.

Hay productos que se consideraban esenciales e imprescindibles en un banquete, por ejemplo la carne y el vino, porque eran los más apreciados por toda la sociedad. En la época moderna no tendría sentido un banquete a base de verduras, que eran productos poco valorados, considerados propios de rústicos, que los comían diariamente. Los ricos no celebrarian un banquete con comida de campesinos y gentes humildes, los pobres querrían salir de la rutina diaria. Igual pasaba con las bebidas, no se comprendería beber sólo agua, el vino se bebía habitualmente por todos, en un banquete se bebería más cantidad, vinos de mejor calidad y vinos variados. Dentro de la carne, el alimento noble por excelencia, destacaba sobre todo la de algunos animales, por ejemplo la volatería y la ternera, existiendo algunas partes del animal más valoradas que otras. Es preciso señalar la importancia del dulce en la alimentación en general y sobre todo en la alimentación de lujo y de fiesta y, por tanto, en los banquetes, agasajos y refrescos. El dulce era considerado lo exquisito, lo caro, lo superfluo, el puro goce de los sentidos. Se le atribuian, además, propiedades eróticas. Un buen ejemplo es en la España moderna el enorme éxito del chocolate, exótico, caro, prestigioso, un verdadero manjar de reyes ${ }^{4}$.

Cambiaban los productos y cambiaban los platos y los menús. En los banquetes había más platos y mejores y en los banquetes de etiqueta se servian en un orden especial, diferente al de los días ordinarios, un orden

\footnotetext{
4 PERlz SAMPER, María de los Ángeles, "La integración de los productos americanos en los sistemas alimentarios mediterráneos", en La Mediterrània. àrea de convergència de sistemes alimentaris. Palma de Mallorca, Institut d’Estudis Baleàrics, 1996, págs. 89-148.
} 
más complejo, constituido por los llamados "servicios", que consistían en cubrir sucesivamente la mesa con un conjunto de platos, unos platos que no se colocaban al azar, sino de manera ordenada, siguiendo un plan establecido. Se hacían dibujos con los platos, con una distribución en función de criterios gastronómicos de combinación de productos, salsas, acompañamientos, en función de gustos, sabores, olores y texturas, normas estéticas de combinación de formas y colores. El conjunto se completaba con centros de mesa artísticos, de flores, de ahí el nombre que se les daba en el siglo XVIII "ramilletes", o de objetos de arte, arquitecturas y figuras de todas clases, fabricados en metales preciosos, porcelana, cristal. Las decoraciones se completaban con más flores, ramas verdes, frutas, distribuídas por toda la mesa y la iluminación se hacía generalmente con velas sostenidas por suntuosos candelabros. Por ejemplo, las mesas propuestas para banquetes por Juan de la Mata en su obra Arte de repostería muestran el diseño de los "ramilletes y las "simetrías", tal como se denominaban en el siglo XVIII ${ }^{5}$. Y se tenian también muy en cuenta las reglas de etiqueta, que recomendaban que todos los comensales debían tener cómodo acceso a los diferentes productos y, como máximo, aconsejaban que los más cercanos a cada plato los aproximaran a los más lejanos, pero sin crear desorden y confusión, como ocurriría pasándose platos de un extremo a otro de la mesa. Martínez Montiño, el cocinero real, en su Arte de Cocina de 1611 explicaba la importancia de servir bien un banquete:

«... en los banquetes todo el toque está en saberlos servir; porque aunque se gaste mucho dinero en un banquete, si no se sirve bien, no luce, y se afrenta al señor mucho habiendo desórdenes en él: y algunas veces las está mirando el Señor, desde su asiento en la mesa. (...) Después que esté asentada la vianda en la mesa, tendrá cada caballero delante de sí de todo quanto hubiere en la mesa, y que lo pueda alcanzar todo desde su asiento, que eso han de tener los banquetes, que cada caballero que estuviere en la mesa, tenga en su bufete de todo quanto hubiere en la mesa, que aunque la mesa sea muy larga, y la mirare toda, no vea cosa que no tenga delante de sí, que si el caballero viese alguna cosa en la mesa que no la tuviese delante de sí, no estaría bien servido el banquete, porque la mayor falta que puede haber en los banquetes es servirse mal ó faltar algún plato; porque claro está, que si habian de ser seis pabos, y hurtasen uno desde la Cocina a la mesa, y no pareciesen allá mas de cinco, que quedaría un bufete sin pabo, y se echaria luego de ver; y si faltase todo un servicio, que son seis platos, no se echaría de ver en la mesa; si no fuese quien supiese de toda la vianda: y

Mata, Juan de la, Arte de reposteria, en que se contiene todo género de hacer dulces secos, y en liquido, vizcochos, turrones, y natas: Bebidas heladas de todos géneros, rosolis, mistelas, \& con una breve instruccion para conocer las frutas, y servirlas crudas. $Y$ diez mesas, con su explicación. Madrid, Antonio Marín, 1747, ed. facsimil. Burgos, 1992, págs. 188-196. + 10 láminas. 
por eso se ha de tener muy grande cuenta, y hacer mucha diligencia, para que entren los servicios enteros en la mesa; pues es todo el toque de que parezca muy bien el banquete, ó que se haga una falta muy grande» ${ }^{6}$.

El lujo no residía sólo en los alimentos propiamente dichos, sino en el entorno. Complementario a comer bien era decorar el plato, la mesa y el comedor. El adorno tenía una triple escala, la del comedor con los famosos aparadores de plata y objetos preciosos, la de la mesa con los ramilletes y simetrías, y la del plato con la disposición de los alimentos, debidamente presentados, y su decoración con salsas y acompañamientos. El mismo acto de comer se transformaba al emplear utensilios de mesa más numerosos y más ricos, de materiales y facturas de calidad, y rituales de mesa diferentes, más complicados y sofisticados, que abarcaban desde el modo de sentarse a la mesa y de servir la comida, hasta la manera de utilizar los cubiertos. En los grandes banquetes todo estaba perfectamente codificado y ritualizado, desde el gesto a la palabra. Los manuales de urbanidad explicaban la actitud que debía adoptarse ante la comida, las posturas, los gestos y buenas maneras, las palabras y conversaciones. También influian las horas, que podían ser distintas, y según la hora del día el banquete adoptaba características diferentes, pues no era lo mismo una comida que una cena o un refresco.

El escenario era también variado. El comedor podía ser uno solo o varios, la mesa una sola o varias, rectangulares o redondas, que eran más informales pues en ellas no existía un lugar preferente diferenciado, mientras normalmente la presidencia, aunque pudiera estar situada en diversas posiciones, solía estar determinada por la forma de la mesa, ocupando siempre el lugar central. El servicio también variaba a la hora de marcar jerarquías, podía hacerse unos después de otros, comenzando por las personas principales, o podía hacerse todos a la vez, siempre que existieran suficientes servidores, o de manera casual o desordenada. Los alimentos podían ser todos iguales o podían haber diferentes menús o platos para cada comensal o grupo de comensales.

El banquete se hallaba estrechamente relacionado con el espectáculo. En ocasiones los grandes banquetes incluían espectáculos, característica

Martinez Montiño, Francisco, Arte de Cocina, Pasteleria, Vizcocheria, y Conserveria. Madrid, 1611, ed. actual facsímil. Barcelona, Tusquets, 1982., págs. 9-13. Sobre los recetarios españoles vid Pérez Samper, M. A., "Los recetarios de cocina (siglos xV-xVIII)", en Profeti, M.G. (ed.), Codici del gusto. Milán, Francoangeli, 1992, págs. 152-184. Entre los muchos recetarios de la época moderna en los que se trata el tema de los banquetes. preparación, menú, servicio, cabe citar especialmente el de Messibugo, Cristoforo da, Banchetti. Composizioni di vivande e apparecchio generale. Ferrara, 1549 , ed. actual, Padua, 1992, $2^{\mathrm{a}}$ ed. 
muy típica de los banquetes medievales. Hacian intermedios para contemplar bailes, música, canciones, juegos, poemas, pequeñas representaciones teatrales, en esos ratos se comían los "entremeses", platos muy variados que tenían en común el ser fáciles de comer, para poder prestar atención a los espectáculos. La música era un acompañamiento habitual de los banquetes. Desde la edad media y a lo largo de toda la Edad Moderna muchos compositores, algunos de ellos muy famosos, compusieron música de corte para las comidas reales y para los grandes banquetes. Con frecuencia los conciertos, bailes, comedias, óperas, fuegos artificiales y otros espectáculos precedían o seguian al banquete. A veces el propio banquete era en sí mismo un espectáculo. Se servían platos decorados de manera fantástica, pavos reales, cisnes y faisanes asados con sus plumas, para simular que estaban vivos, pasteles que se abrían y volaban pájaros vivos. Los cocineros y a veces incluso artistas consagrados creaban figuras de diferentes productos, gelatinas, pastas, muchas veces de azúcar. El gran Leonardo da Vinci, entre sus muchas actividades, fue maestro de banquetes en la corte de Ludovico Sforza durante muchos años y diseñó platos y decoraciones de mesa, así como máquinas para utilizar en las cocinas?

A lo largo del tiempo los banquetes fueron cambiando. Algunos ejemplos concretos pueden resultar ilustrativos. Un banquete celebrado de acuerdo con el ceremonial borgoñón, introducido en la corte española por la Casa de Austria, puede ser un buen ejemplo de banquete altamente jerarquizado, expresión de abundancia y refinamiento, modelo de banquete renacentista. Carlos de Habsburgo, que acababa de convertirse en rey de España, antes de viajar a la península, celebró en Bruselas la fiesta del Toisón de Oro, que incluia un espléndido banquete. Laurent Vital narró con gran detalle el festín, que tuvo lugar en el palacio real el 25 de octubre de 1516:

"La gran sala estaba toda tapizada con una hermosa tapicería representando la historia de la ceremonia del Toisón, hecha de oro, plata y seda. En la sala donde comieron el Rey y todos sus compañeros de la Orden estaban aderezadas tres mesas. Una que estaba ante la chimenea era para dicho señor Rey; estaba cercada por un enrejado hecho a manera de celosía, elevada sobre un estrado de tres o cuatro gradas de alto, y tenía un rico dosel de cielo tapizado. Fuera de este recinto habia dos mesas a ambos costados. Una era para comer en ella los caballeros de la Orden del Toisón, que estaban todos sentados a un lado, dando la espalda a una tapicería de oro y

Notas de cocina de Leonardo da Vinci, compilación y edición de S. y J. ROUTH. Madrid, 1996. 
plata con historias de personajes del Rey Alejandro de Macedonia; la otra mesa, que estaba en el lado opuesto, era para los oficiales de la Orden: canciller, escribano y el oficial llamado Toisón. No habia oficial ni caballero comiendo en aquel lugar que no estuviese servido con tantos platos y servicios como lo fue el Rey, a saber: cada vez con una fuente de carne, seguida de dieciocho o veinte platos más, renovados cinco veces y en tal modo, que no había nadie de los que alli comian sin ser servidos con cien diversos manjares.

La manera cómo fueron servidas las viandas, ciertamente fue digna de ver, pues fue algo muy exquisito y magnífico (...). Todos los servicios y los diversos manjares fueron presentados en fuentes de plata por cortesanos acompañados de las trompetas de dicho señor Rey y de los maestresalas que los dirigian.

En verdad, era un sueño el ver la diversidad de los servicios y la ciencia de los criados, cocineros y pasteleros para preparar pavos reales, cisnes, faisanes y perdices asados, adornados y revestidos con sus plumas tan bien, que parecian que estuviesen vivos; eso sin contar las otras diversas carnes de cazuela y horno, en tan gran abundancia, que no cabía más.

Había alli castillos levantados, hombres salvajes, caballeros, sirenas de mar hechas con gelatina, mermeladas y pasta, y también monstruos y quimeras tan artificiosamente hechos de modo insuperable. También habia tartas, flanes, galletas y muchas clases de compotas de frutas, almíbares y mazapanes, y todas las cosas que, según la estación, es posible encontrar. Entonces fue servida la nobleza con muchas clases de vino, blancos y tintos, y con buena cerveza, a fin de que todos tuviesen lo que pidieran. Durante esta comida llegaron unos músicos para tocar varias clases de instrumentos ante el Rey y la nobleza, y los cantores cantaron alli varias buenas canciones.

Después de haber comido mucho se retiraron las viandas para servir al Rey barquillos e hipocrás. Luego liegó el dar a lavar las manos con diversas aguas olorosas de tan buen olor, que el sitio parecía estar embalsamado" ${ }^{8}$.

El banquete era un acto de creación, una obra de arte. Aunque fuese efímera, destinada a desaparecer, su memoria era digna de ser conservada para la fama. En la época moderna eran numerosas las relaciones que se publicaban explicando las fiestas y dedicando mayor o menor atención a los grandes banquetes ${ }^{9}$. El alimento mismo, tal como ya se ha ex-

\footnotetext{
* Vital, Laurent, Primer viaje a España de Carlos I con su desembarco en Asturias. Oviedo, 1992, págs. 63-64.

9 Vid, por ejemplo, Cubillo de Afagon, Álvaro. Relación del Combite y Real Banquete, que a imitación de los Persas hizo en la Corte de España el Excmo. Sr. D. Juan Alfonso Enriquez de Cabrera al duque de Agramont. Embajador del Rey de Francia Luis XIV, en ocasión de pedir la mano de la Infanta Dña. Maria Teresa de Austria y Borbón. Madrid. Andrés Garcia de la Iglesia, año 1659. Según este relato se sirvieron en el banquete ochocientos platos, quinientos de carne y trescientos de principios y postres.
} 
plicado, se convertía en fiesta y en espectáculo y se introducían elementos de fantasía. En el banquete del Toisón de Oro citado se habla de las figuras representadas con los productos alimenticios. La mayoría de las veces estos platos eran más para adornar que para comer.

La fantasía era importante y muchas veces en los banquetes habian retos a la vista y a la imaginación, cosas que aparentaban ser otras, productos que cambiaban de formas y colores. La simulación y el engaño eran a veces un recurso, aunque su empleo no fue siempre igual valorado por las normas gastronómicas, en unas épocas se buscaba engañar, desconcertar y los cocineros creaban platos que eran auténticos utrompe l'oeil'”, en otras se buscaba la autenticidad y era importante que las cosas tuvieran su olor, su color y su sabor naturales.

El mismo banquete en su conjunto y en su transcurrir se transformaba en un espectáculo, en el que los comensales eran a la vez actores y público. Incluso era costumbre, considerada honrosa, que algunas personas fueran invitadas a contemplar cómo celebraban otros el banquete. Ver comer al rey, asistir a la ceremonia de la comida real en público constituía un gran honor para los personajes que tenían acceso al comedor regio. En la reservada corte española de los Habsburgo, de acuerdo con el ceremonial borgoñón, el rey comía habitualmente solo, rodeado de algunos cortesanos y servidores, y la reina comía también sola, acompañada de sus damas, y únicamente en ocasiones extraordinarias comian juntos y en público. Cuando se celebraba alguna fiesta especial, se podian cambiar las rígidas y severas costumbres y comer junta la familia real en un ambiente igualmente ceremonial, pero más alegre y festivo, con un acompañamiento musical. En el siglo XVII Luis XIV introdujo en Versalles el ritual de la comida real en público como parte de la vida cotidiana de la corte francesa y los Borbones españoles siguieron esta costumbre en el siglo XVIII.

El testimonio de Jean Lhermite, que nos ha dejado el relato de una fiesta en el Alcázar de Madrid a fines del reinado de Felipe II, puede servir de ejemplo de un lujoso banquete regio al estilo español en la corte de los Austrias:

"Esta estancia (la sala grande) se hallaba ricamente adornada con un tapiz muy estimable que representaba la conquista de Túnez, todo él ejecutado sobre una tela hermosísima ornada con colores bellos y muy vivos realzados o iluminados por el oro y la seda. Y en esta sala se pusieron y alzaron algunas mesas y muebles, y al final de ella se colocó su trono, de magnificencia verdaderamente real, bajo el cual se sentaron a la mesa. Dije que había cinco palios dispuestos consecutivamente. Había uno para cada personaje, y todos ellos estaban ricamente elaborados y adornados con perlas y piedras preciosas, bordados y hechos con punto de aguja, que era una 
cosa que causaba mucha admiración. Todos los asientos eran de oro tejido y estaban alineados. Se sentaron en ellos los cinco siguiendo el mismo orden que habian observado en la iglesia, a saber la reina en la mitad de todos, a su derecha el rey, y a la suya el archiduque, y a la izquierda de la reina estaban el infante y al suyo la archiduquesa. Todos ellos fueron servidos por los gentileshombres de boca y por sus damas y sirvientas, que todos ellos saben hacerlo maravillosamente, observando en todo las ceremonias de la grandeza y boato real, y que en casos semejantes suele emplearse. Eran las cinco de la tarde y todavía no se habían sentado. Trajeron la carne, que llegó en bastante buen orden, y la llevaron los gentileshombres de boca del rey y del archiduque; delante de ellos iba el gran maître y todos los demás; sostenía su bastón en la mano y durante la cena hubo música de clarines y trompetas en la corte de Palacio. Y en la misma sala no faltó ningún género de música. Se tocaron toda suerte de instrumentos musicales, que oía complacido el rey, cosa digna verdaderamente de ser vista y de guardar en perpetua memoria. $Y$ todas las mujeres, salvo las que aquel dia servían la mesa, se colocaron a lo largo de las paredes de la mencionada sala, y allí se mantuvieron de pie durante esta real cena contemplando a los gentileshombres que allí abundaban. Llevaban todos ellos la cabeza descubierta, salvo los Grandes de España, quienes se cubrian (como ya hemos dicho en diversas ocasiones) delante del rey, y en la sala hubo durante toda la noche toda clase de música, como también se ha dicho. Terminada la cena, estos cinco personajes se retiraron cada uno a su cuarto y dejaron su lugar a las damas y gentileshombres. Eran las ocho de la tarde y las mesas todavia no se habían levantado. Una vez puesto todo en buen orden, volvieron Sus Magestades y Altezas a la mencionada sala, y a ellos les siguieron las damas, y se sentaron en sus asientos y debajo de su trono como antes habian hecho, y todas las damas lo hicieron también en los lugares que les había asignado el maître, esto es, sobre los tapices de Turquía hechos en seda y cuadrados de tela de oro de muy grande valor, todo ello puesto en buen orden, a saber, a todo lo largo de la sala por uno y otro lado, de dos en dos por cada cuadrado, de tal modo que hubo bastante espacio para que los gentileshombres se encontrasen a gusto en el festín, del que disfrutaron con el recato y nobleza que debe observarse en presencia de tales príncipes" ${ }^{10}$.

El relato de Jean Lhermite resulta bien expresivo del lujo y ceremonial de la corte y presenta muy claramente la dimensión de espectáculo que tenía siempre, pero mucho más en las grandes festivades, el mundo cortesano. Este gran banquete fue en realidad un doble y curioso espectáculo, primero comió la familia real servida y contemplada por sus cortesanos

10 Lhermite, Jean, Le Passetemps, según el manuscrito II, 1028 de la Biblioteca Real de Bruselas, eds. Ch. Ruelens, E. Ouverleaux y J. Petit, Amberes, 1890-1895, 2 vols. XLIV-314, P, págs. 219 y ss. Citado en el apéndice de fuentes escritas en El Real Alcázar de Madrid. Madrid, Nerea, 1994, págs. 492-493. Otros datos sobre festines en la corte española de la segunda mitad del siglo XVI en ABAL A López, Arturo, "Un banquete a Felipe Il", Hispania, VI, 1942, págs. 286-297. 
Fiesta y alimentación en la España moderna: el banquete como imagen festiva...

y servidores, después comieron los cortesanos, contemplados por la familia real. El festín fue el centro del espectáculo y los actores y espectadores intercambiaron los respectivos papeles.

La escenografía del banquete era siempre muy importante. El marco de la representación era fundamental, pues la decoración del comedor y de la mesa adquirían protagonismo, en consonancia con el contenido alimentario. Un típico banquete barroco ofrecido por el duque de Lerma, el gran valido de Felipe III, en Valladolid el 7 de junio de 1605, en honor de Lord Nottingham ${ }^{11}$, embajador de Inglaterra ante la corte de España, constituye un buen ejemplo del lujo y el ritual que rodean la preparación y celebración de un gran banquete cortesano, que adquiere categoría de espectáculo. Según explicaba el portugués Tomé Pinheiro da Veiga:

«Este día dio el duque un banquete esplendidisimo a los ingleses, que se afirma fue de los más notables y de más ostentación que hace mucho tiempo se dio; y para más aparato mandó hacer la comida en unas cocinas fuera de su patio grande y se hizo un pasadizo con cuatro columnas de madera de cada parte, cubiertas de brocados con toldo encima, para que pasaran los manjares por debajo, y la plaza y explanada se adornó toda de muy ricas colgaduras para esta procesión.

Se hicieron tres aparadores en tres habitaciones; uno que cogia toda la pared de alto a bajo, con peldaños en la misma forma y pared frontera para la plata, en que había como 400 vasos, todos de invención hermosisima, a más de la plata ordinaria.

En la otra habitación estaba la vajilla de oro y esmaltes, toda de piezas notables, que ocupaba la mesa y gradas de una pared hasta arriba, cosa admirable de ver; y en la otra habia solamente vidrios y cristales engastados en oro, con pies, asas y tapas de oro y labores en toda su extensión, y los vidrios de colores, cosa nobilísima; de manera que no sé qué rey de la cristiandad podía tener más hermosa y rica vajilla (...).

El banquete se dio en una galería grande, armada de brocados, como las demás de las cosas, donde pusieron 24 alacenas por medio de la casa para 80 personas, que comieron a la mesa con el Almirante, y estando con él en la sala muchos señores y títulos y muchas damas y señoras rebozadas, que todos entraron con asaz trabajo.

Estaban las mesas con servilletas de figuras y el pan cortado en invenciones, y los saleros, con servilletas de varios géneros de flores y animales, y los antes con flores como en arco, con castillos y labores doradas y plateadas.

Sirvieron a la mesa 24 pajes del Duque, de librea negra para aquel día, cueras blancas y cadenas de oro, y el maestresala, copero y mayordomo y otros criados de igual suerte.

Se trataba de Charles de Howard, Conde de Nottingham, almirante de Inglaterra e Irlanda. 
Estuvieron el rey y la reina viendo todo por una celosía que quedaba frente al extremo de la mesa, escondidos; y se afirma que sirvieron a la mesa 2.200 platos de cocina, y que fue de ver, además, los dulces secos, los frascos de conservas, y sobre todo la invención de empanadas de mil figuras de castillos y navios, todo dorado y plateado. (...)

Concluyo con el banquete, en que había todo género de músicas e instrumentos, mientras duró la comida, que fue hasta cerca de las cuatro (...). (Después) hubo comedia en un jardín del duque, todo entoldado por encima; y las ventanas que van alrededor de los arcos, con vidrieras" ${ }^{12}$.

En este caso el testigo, aunque se extiende en relatar la rica ornamentación, no explica el contenido gastronómico del banquete, pero en otra ocasión un poco posterior, con motivo de la fiesta de Corpus Christi, el 13 de junio, Pinheiro da Veiga, además de recoger interesantes detalles de la etiqueta y el servicio de la mesa, ofrece con minuciosidad el espléndido menú que por cuenta del rey de España se sirvió al embajador inglés, a su séquito y a un gran número de invitados españoles que les acompañaban:

"Digo ahora que las personas a que se daba de comer pasaban de 700 . y que con ellos comían a la mesa 62 ingleses nobles, en una sala grande donde hacia el medio había una mesa grande de alacenas, que la atravesaba toda, con bancos acolchonados de respaldo de una parte a otra

A la cabecera, debajo de un dosel, se sentaba el almirante en una silla de brocado; a su mano derecha el conde irlandés, sobrino del rey, al cual daba silla, mas él no se sentaba en ella sino pocas veces; a mano izquierda quedó su sobrino mayor ${ }^{13}$, y luego el hijo del estribero mayor del rey de Inglaterra, y el conde de Norris abajo; los demás sin orden, y entre ellos el hijo más mozo y el yerno del almirante.

Tenía cargo de proveerlos el aposentador mayor, Gaspar de Bullón, que muchas veces comía con ellos, y servian además otros dos criados del rey cubiertos y otros 24 hombres ordinarios, que llevaban los platos. El servicio ordinario era de 260 platos de cocina grandes, contando todos los que se ponian en la mesa con comida, $y$ en ellos como 24 cosas diferentes, entrando los antes y postres, a saber 4 ó 6 de antes y otros tantos de sobrecomida, y dos servicios, que es comida perfecta, por dos veces; y, para mayor claridad, pondré una cena y una comida.

Cuando se sientan a la mesa, están en ella los antes y los postres, que eran estos: Antes: guindas, limas dulces, almendras y pasas, orejones y natillas; todo repartido por 48 platos grandes. Sentáronse a la mesa sin oración

12 Pintieiro da Veiga, Tomé, Fastiginia. Vida cotidiana en la corte de Valladolid. Valladolid, Ayuntamiento de Valladolid, 1989, págs. 117-118.

13 Debe decir su hijo mayor, según el manuscrito del Museo Británico. 
ni lavarse las manos, ni cumplimiento alguno, sino sentarse y comenzar a comer.

Luego 24 criados con dos platos descubiertos, cada uno en una mano, y en uno venía olla de vaca, carnero y gallinas, en el otro palominos, como media docena en cada plato. El segundo servicio fue de los mismos 24 criados, el primero en una mano ternera asada, en la otra hojaldrada; el segundo pavo y pasteles; el tercero, lo mismo que el primero, y así los demás.

Volvieron tercera vez, trayendo gallinas y arroz con leche y carnero asado, repartiendo todo en 48 platos, y asi más vaca cocida y torta. Eran los postres: cajas de mermelada, aceitunas, acitrón, confites, obleas, grajeas, medios quesos y cerezas.

La cena, por el mismo orden, fue ésta: Antes: ensalada, alcaparras, rábanos y espárragos; primer servicio, pasteles y ternera frita con huevos, pernil y pichones, pato albardado y olla; segundo, perdiz, capones rellenos, otra olla y pierna de carnero, jigote, cabrito, ternera y cabezuelas; postres, peras cubiertas y rábanos, suplicaciones y aceitunas, otras peras y medios quesos.

En llegando los platos, toma el que sirve dos del primer criado y los pone en la mesa, y quita otros dos que le dan; y así van limpiando y proveyendo la mesa.

En el servicio y comida del almirante no hay más diferencia que en el beber, que se lo sirve su copero de rodillas, y un criado del rey le da la toalla entre dos bandejas. Comen muy a lo hidalgo, limpia y concertadamente; comen poco y beben menos, y sin comparación menos de lo que nosotros bebemos en un banquete.

Usan unos vasos grandes de vidrio de limonada, que es vino aguado, que lleva azúcar y trozos de limón nadando; con estos brindan y van corriendo la mesa: llevaron una canada ${ }^{14}$. Acabada la comida, se lavan las manos y se retiran, y noté que no bendicen la mesa, ni dan gracias a Dios" 15 .

En ocasiones la corte organizaba banquetes más informales, que se basaban en la recreación de platos populares, como sucedió por ejemplo en la gran comida que relata Jerónimo de Barrionuevo en sus Avisos, celebrada en el real sitio de la Zarzuela en enero de 1657, en que se ofreció a los invitados una monumental "olla podrida", acompañada de muchísimos platos más:

«Miércoles 17 de éste se hizo en la Zarzuela la comedia grande que el de Liche tenía dispuesta para el festejo de los Reyes (...). Hubo una comida de 1.000 platos, y una olla disforme en una tinaja muy grande, metida en la tierra, dándole por debajo fuego, como a horno de cal. Tenia dentro un becerro

Medida portuguesa, equivale a cerca de un litro y medio.

Pinheiro da Veiga, Tomé, op. cit., págs. 142-144. 
de tres años, cuatro carneros, 100 pares de palomas, 100 de perdices, 100 de conejos, 1.000 pies de puerco y otras tantas lenguas, 200 gallinas, 30 perniles, 500 chorizos, sin otras 100.000 zarandajas. Dicen que costó 8.000 reales, siendo lo demás de ello presentado. Todo cuanto aquí digo es la verdad, y ando muy corto, según lo que cuentan los que allá se hallaron, que fueron de 3.000 a 4.000 personas, y hubo para todos, y sobró tanto, que a costales lo traían a Madrid, y yo alcancé unos relieves o ribetes. Todo esto, fuera de las tostadas, pastelones, empanadas, cosas de masa dulce, conservas, confituras, frutas, y diversidad de vinos y aguas extremadas" ${ }^{16}$.

Otra versión de un banquete del siglo XVII, pero más común, sin el lujo y las sofisticaciones de la corte, nos lo ofrece, por ejemplo, un viajero extranjero, Bartolomé Joly, un eclesiástico de alto rango, a través de la detallada descripción y los comentarios que hizo a propósito de una gran comida que le fue ofrecida en Barcelona, en 1603, en vísperas de las fiestas navideñas ${ }^{17}$. Resulta muy ilustrativo el relato, tanto para conocer el contenido alimentario de una comida, los platos que se presentaban a la mesa y además el orden en que eran presentados, como también para conocer las costumbres del servicio y de los comensales.

Una observación se refiere al modo de servir la mesa. El que la mesa todavía no tuviera dispuesto el primer servicio cuando los comensales tomaban asiento extrañaba a Joly. Según relata, sirvieron los platos unos detrás de otros, estilo que a Joly le parecía una buena solución, pues aseguraba comer los platos calientes, ya que de presentarlos todos a la vez era muy difícil que no se enfriaran: «Del servir cada plato aparte les viene esa comodidad de comerlo caliente, que es la verdadera toma."

El banquete comenzaba con un entrante a base de frutas variadas y ensaladas, que eran cortadas y distribuidas ceremonialmente por el maestresala a cada uno de los comensales, de acuerdo con su categoría. Siendo España un país rico en frutas muy variadas y de gran calidad, no es de extrañar que las frutas ocuparan un lugar destacado del menú, abriendo los festines. Por esas mismas fechas, el cocinero real Martínez Montiño también colocaba las frutas como elemento importante de los grandes banquetes de la corte. Según escribía Joly:

i6 BarRionuevo, Jerónimo, Avisos, vol. II (1654-1658), B.A.E., Tomo CCXXIl. Madrid, 1969 , pág. 53. Madrid y enero 23 de 1657. Banquetes campestres los hubo tamosísimos, por ejemplo el celebrado en Doñana, ofrecido por el duque de Medinasidonia al rey Felipe IV en 1624, vid. Alonso, Juan Carlos, El tan célebre banquete de Doñana. Huelva, Patronato del parque nacional de Doñana y Diputación Provincial de Huelva, 1995.

17 Garcia Mercadal, José, Viajes de extranjeros por España y Portugal. Madrid, Aguilar, vol. II, 1959, págs. 52-53. 


\begin{abstract}
"Y primeramente viene la fruta, que comen, al contrario que nosotros, lo primero: naranjas enteras y en rodajas azucaradas, ensaladas, uvas verdes, granadas, melones de invierno que llaman invernizos, guardados todo el año como en conserva. Asi pues, puestos los platos, el maestresala se coloca en el extremo de la mesa, descubierto, con su capa y su servilleta al hombro. A un lado una pila de platos; al otro, un gran cuchillo y un tenedor, con el que hace las partes, tomando un poco de cada fruta, que pone sobre un plato primero al más calificado, sirviendo de ese modo a los tres o cuatro más próximos a él; algún otro de los más diestros hace semejantes platillos a todo el resto de la mesa, de manera que nada quede en los platos, que son retirados poco después, y otros suceden en su lugar; lo mismo con los platos."
\end{abstract}

Después del entrante de frutas y ensaladas, seguian los platos de carne, tanto asados como guisados, que se trinchaban también cuidadosamente, bien en la cocina, como dice Joly, o bien en la mesa, para aprovechar bien la pieza, para realzar su calidad gracias al corte experto y para poder repartirlo de la mejor manera posible entre todos los comensales. En opinión de Joly, presentar las carnes ya partidas era un acierto, porque evitaba pérdidas de tiempo: «En cuanto a servir las viandas todas partidas, encuentro que tienen razón, no habiendo nada que tenga tanto valor en la mesa como el tiempo, del cual no siempre se sirve uno bien."

Otra particularidad que Joly señalaba era la costumbre de que cada comensal comiera en su propio plato. Este hábito, que representaba un gran avance en las medidas de higiene era, además, una clara manifestación de civilidad y refinamiento.

Entre los platos de carne destacaba la habitual preferencia por la volatería, encabezada por los pavos venidos de América, que tan rápido éxito tuvieron en las mesas españolas de las clases acomodadas. También se ponía de manifiesto en la composición del menú la afición a la caza, caza menor, como perdices o conejos. Los asados se servian acompañados de salsas variadas, que cada comensal utilizaba de acuerdo con sus gustos. Los platos de carne se alternaban con las tradicionales cremas dulces, tan apreciadas desde la Edad Media, como el famoso manjar blanco, la crema de almendras o el arroz con leche, que servían como una especie de contrapunto suave, pero también especiado, a los fuertes y condimentados platos de carne. La mezcla, combinación y alternancia de sabores diversos y aún contrapuestos, salados, dulces, agrios, agridulces, picantes, ácidos, era una de las características de la cocina de la época. Al final, las típicas aceitunas y como culminación el gran plato de cocido, la olla, el más tradicional de los platos de la cocina española de la época moderna:

“Las más gruesas viandas, como pavos, conejos, capones, pollos, no están nunca enteros, sino partidos en pedazos desde la cocina, de tal modo 
que apareciendo una gran fuente o dos de pavo, el maestresala sirve el plato, cortando más menudo para dar con la salsa dos o tres pedazos a cada uno. Retirado eso y cambiados los platos, vienen los conejos, con los que se hace lo mismo; las gallinas y los pollos rellenos de ajos, las pechugas de pichón. Entre todo eso se hará un servicio a cada uno de su escudilla de pisto de leche y azúcar amarillo, sin pan y muy especiada, una de una leche de almendra con azúcar, a la cual sucede cierto manjar blanco bastante bueno, y siempre a cada uno su platillo: de arroz también espolvoreado de azúcar y canela mezclados juntos, que llaman polvo de duque. Vienen después las perdices bien cortadas, salpicadas de pimienta entre las alas y las patas, pero manteniéndose todavía en su forma, todo ello asado y sin tocino; por fin, las aceitunas; después, el cocido, lo último."

Como casi todos los viajeros, Bartolomé Joly denunciaba la pasión española por la sal, las especias y los condimentos picantes y de fuertes sabores, como el popular ajo. Los platos, ya cocinados con grandes cantidades de especias y condimentos, eran todavía más salados y especiados en la mesa, de acuerdo con el gusto particular de cada comensal. Según Joly esta afición a las especias no era un simple capricho de los paladares españoles, sino que la costumbre venía avalada por la medicina, pues se consideraba favorable para la digestión:

«... hay que beber más que de ordinario a causa de la gran cantidad de pimienta que ponen en todas las viandas, además de la que sirven en la mesa como sal, estando hechos sus saleros para tener uno y otro, no dejando de especiar para hacer, dicen ellos, una buena digestión; la libra de pimienta cuesta allí dos reales. Comen, además de eso, rellenos de ajo, y otro ajo machacado y líquido, teniendo un proverbio sobre el buen comer, el ajo, con sopicaldos y guisados que llaman sainetes, no perdonando nada que esté muy sazonado de especias".

Acompañamiento obligado del banquete eran las bebidas, especialmente el vino, blanco y tinto, sobre el que Joly no se muestra muy favorable en cuanto a su calidad, pues lo considera demasiado fuerte, en comparación a los vinos franceses a los que estaba habituado. De todos modos, se constata la costumbre de beber el vino aguado, cada comensal en la proporición que deseara. Resultan muy interesantes sus explicaciones sobre el modo de servir el vino y la manera de beberlo:

"Cuando alguien quiere beber, lo traen del buffet, llamado aparador, que de ordinario está fuera de la sala, adornado no solamente con vasos para beber y utensilios de mesa, sino con otras piezas y joyeles exquisitos, si el dueño los tiene para hacer en honor a sus amigos una recepción más digna; traen, pues la copa medio llena de agua, presentada sobre un plato un poco hondo, en el que se puede verter lo sobrante, y todo el vino que se quiere, siéndole servido, blanco y tinto, en dos pequeños jarros de vidrio. El vino se 
Fiesta y alimentación en la España moderna: el banquete como imagen festiva...

sube a la cabeza y no es delicado como el nuestro (...). El español no brinda apenas, ni ofrece de beber el uno al otro, pero entonan de tal modo que, levantando la nariz y la mano a un tiempo, todo lo han tragado antes de que nosotros hayamos empezado a llevarlo a la boca. La forma de sus vasos, que ellos llaman penados, penosos, porque tienen el borde vuelto para afuera, les llena de aire y eructan en la mesa sin ruborizarse; los más educados eructan en su servilleta, poniéndosela delante de la boca."

Como fin del banquete venían los postres dulces, pues el dulce era otra de las grandes pasiones del gusto alimentario español en la época moderna. No podía celebrarse un banquete digno de tal nombre si no se presentaba en la mesa como colofón una variada muestra de pastas, dulces, confituras y, sobre todo en tiempos navideños, los tradicionales turrones, que Joly define de manera muy curiosa. Los postres se solían acompañar de vinos especiados, como el tradicional hipocrás, famoso desde la Edad Media:

«Al fin, retirado el cocido, traen para postre lo que llaman, a diferencia de la entrada, fruta de postre, confituras y también turrones, especie de bizcocho muy duro, hecho con azúcar para humedecer en el hipocrás, compuesto con canela y a veces con ámbar gris; llaman a eso lavadientes, que la mayor parte toman después de quitado el mantel."

La mesa era siempre y también en la España moderna un lugar de encuentro y de conversación, que debía ser siempre apropiada a las circunstancias, evitando aquellos temas que pudieran dar lugar a discrepancias o debates inoportunos, que llegaran a arruinar el placer de comer. Joly consideraba que la actitud de los españoles en la mesa se dirigía a especialmente a disfrutar de la comida: «La plática general de su mesa es mostrar gran interés por la comida, mezclando un poco de conversación para animarse a comer bien.»

La alimentación en el siglo XVIII, de manera especial la de la corte y la de las clases altas, inauguró un gusto diferente y nuevo. Es evidente la ruptura entre la alimentación de alta categoría de los siglos XVI y XVII y la del siglo XVIII. En la corte, dejando aparte los gustos personales, sobre una cierta permanencia de la tradición española de la época de los Austrias, es clara la enorme influencia de la cocina francesa, explicable por el origen francés de la dinastía borbónica, la presencia de cocineros franceses en la corte y el prestigio de la gastronomía francesa. También es notable la influencia italiana, sobre todo en tiempos de Isabel Farnesio, que era italiana, de Carlos III, que había vivido largos años en Italia, y de Carlos IV, tal vez como continuación de la costumbre familiar o tal vez por ascendiente de María Luisa de Parma. 
El modelo de cocina cortesana era, pues, una cocina opulenta, refinada y cosmopolita, que respondía a los más elevados ideales gastronómicos y que se hallaba completamente diferenciada de la cocina popular, separada por una enorme distancia. Sin embargo, como modelo que era, debido al prestigio de la corte, sumado al de la alta gastronomía francesa de la época, el ejemplo cortesano trató de ser emulado por las clases más elevadas de la sociedad española y ejerció una indudable influencia en el paulatino afrancesamiento de la alta cocina española, llegando su inspiración primero a las mesas nobles y después, sobre todo en el siglo xIX, a las mesas burguesas.

Una fuente interesante para conocer la alimentación cortesana son las contratas hechas con los cocineros. Como ejemplo puede servir una contrata del reinado de Carlos III, de 1761, posterior a la muerte de la Reina María Amalia de Sajonia, en la que figuran los menús del Rey y de sus hijos, algunos todavía pequeños ${ }^{18}$. La contrata fue hecha por los jefes de la Real Cocina de Boca de Su Majestad, Antonio Catalán, Juan Tremouillet y Mateo Hervé, en septiembre del año 1761. El precio de los diversos menús ascendía a 2.309 reales de vellón. De ellos, 1.140 reales por la vianda del Rey. Aunque no se trata de una comida extraordinaria, sino del menú ordinario que diariamente se servía a la mesa del monarca, el prestigio de la corte exigía permanentemente un nivel tan alto que el ejemplo constituye un buen modelo de banquete de mediados del siglo XVIII. Según la contrata la comida y la cena del Rey eran las siguientes:

\section{Comida del Rey}

\section{3 sopas}

1 de cangrejos con dos pichones

1 de hierbas con una polla

1 de arroz con sustancia de ternera

10 trincheros

1 de perdigones asados

1 de criadillas fritas

18 Esta contrata, que, a diferencia de las de los otros reinados anteriores o posteriores, no hemos podido hallar en los fondos del Archivo de Palacio de Madrid, fue publicada como un documento proporcionado por el "doctor Thebussem", pero sin citar su procedencia o localización original, por Ignacio DOMENECH en Un festín en la Edad Media. Madrid, 1913, págs. 19-30. Ha sido publicada, en parte, más recientemente por MARTinez Llopis, Manuel M., Historia de la Gastronomia española. Madrid, Alianza Editorial, 1989, págs. 325-330, que cita como procedencia las obras del doctor Thebussem y de I. Domenech. Una panorámica reciente sobre la corte en Simón Palmer, María del Carmen, La Cocina de Palacio 1561-1931. Madrid, Castalia, 1997. 
1 de mollejas de ternera, guarnecidas de cresta y botoncillos de pollo

1 de timbal de macarrones

1 de filetes de gazapos con vino de Champaña

1 de pichones con chuletitas

1 de pato cebado asado

1 de costillas de ternera en adobado

1 de costraditas de polla al blanco

1 de pastelitos a la española

2 entradas

1 de pecho de vaca cocido

1 de tres pollos con jamón

2 asados

1 de dos pollas de cebo

1 de tres pollos o tres pichones

4 postres

1 de cangrejos cocidos

1 de tortas de guindas

1 de artaletes de higadillos de pollas

1 de buñuelos en serpiente

Cena del Rey

3 sopas

1 de caldo claro con dos pichones

1 de arroz con sustancia

1 de pasta de Italia

8 trincheros

1 de perdigones asados

1 de mollejas de ternera en artaletes

1 de filetes de pato con salsa de naranjas

1 de dos pichones en matelota

1 de pavito cebado asado

1 de rebanadas de ternera con aceite

1 de jigote de perdices

1 de polla estofada con vino de Borgoña

1 entrada

1 de lomo de ternera asada

2 asados

1 de pollas de cebo

1 de tres pichones 
3 postres

1 de tartaletas de conserva

1 de rosquillas de pasta Flora

1 de huevos frescos

El banquete era, como la fiesta, la deseada ocasión de romper la rutina de la vida diaria. Tenía, por tanto, un sentido relativo. Podía ser más o menos abundante o más o menos refinado, en función de la norma común y ordinaria. Para una comunidad religiosa sometida a un riguroso voto de pobreza o, todavia más, para los numerosos pobres por necesidad y obligación, un pequeño extraordinario ya podía considerarse un banquete. Cada grupo social tenía un modelo y un ideal de banquete. Romper la norma para los que estaban en el nivel superior era más difícil. ¿Cómo se podía comer más o mejor en la corte? La mesa real de un día ordinario era un banquete, un banquete de tal magnitud que raramente podía ser igualado por ningún otro particular. Pero el que se sirvieran muchos alimentos y de gran calidad no significaba, naturalmente, que el rey comiera exageradamente, la mayoría de los platos ni los probaba, sólo elegía algunas cosas y el resto, que era casi todo, se repartía entre los cortesanos. En palacio el banquete tenía más que ver con un cambio de ritual y de significación.

Sentido simbólico tenía uno de los banquetes más importantes que se celebraba en palacio cada año. En las celebraciones alimentarias de la Semana Santa existía una costumbre en la corte española, que tenía un carácter especialmente revelador, la llamada comida de pobres de Jueves Santo, servida por la Casa del Rey. La comida de pobres de Jueves Santo es un buen ejemplo de banquete, en el sentido de modelo de abundancia, con el factor añadido de que al ser ofrecido por el rey a unos pobres el efecto deslumbrador debía resultar todavía mayor. La cantidad realmente exagerada del número de platos y de su contenido era una clara prueba de poder y condescendencia. Todo aquello no podía realmente consumirse, por mucho que fuera el apetito de los comensales. Estaba destinado a sobrar, para encarnar el mito del alimento inagotable, trasunto de un poder sin límites. Parece que los pobres, incapaces de comerse todo, se llevaban las viandas, para consumirlas posteriormente o repartirlas a la familia y amigos, y con gran sentido práctico muchos las vendían a la salida del palacio, dispuestos a aprovechar la ocasión hasta las últimas consecuencias. A fines del siglo XVII un embajador marroquí recogía en el relato de su viaje por España un interesante testimonio sobre el destino último de las sobras del banquete de pobres de Jueves Santo: "Se van de allí (el palacio) entonces, llevándose todo lo que el 
Rey les ha entregado, así como los restos de la comida y los platos en los que les ha sido servida. Se les ve vender todo eso en las calles, donde la multitud se precipita, a causa de la creencia que tiene en que la bendición va unida a esos alimentos" ${ }^{19}$.

El elemento de prestigio inherente a todo banquete resultaba potenciado al ser la Casa Real la que ofrecía el festín y se veía reforzado todavía más por tratarse de pobres. Anfitrión y comensales se hallaban en los puntos extremos de la escala social. La comida de pobres de Jueves Santo era un gran banquete ritual y un ejemplo del significado religioso y social del alimento como limosna. Era tradicional en la mesa real reservar una parte a los pobres y en lugar de hacerlo diariamente la limosna se concentraba en un día especial, el día de Jueves Santo. Ese día, celebración del amor fraternal cristiano, se veía subrayado por esta celebración simbólica y espectacular de la caridad del más poderoso, el rey, hacia trece pobres, que representaban a los más desvalidos de sus súbditos. El precepto penitencial de la Semana Santa se veía formalmente respetado al tratarse de un banquete de vigilia, compuesto sólo de pescado, con abstinencia total de carne, aunque el sentido profundo se veía en cierto modo transgredido por la cantidad y calidad de las viandas ofrecidas.

Las etiquetas de la Casa Real disponían con todo lujo de detalles la forma de celebrar la ceremonia del "Lavatorio y comida de los pobres del mandato de Jueves Santo":

"S.M. lava los pies y da de comer a trece pobres el Jueves Santo y de ordinario se hace esta ceremonia en la pieza de la antecámara, para lo cual en saliendo S.M. a la capilla los oficiales de la tapicería quitan el dosel y el oficio de la furriera pone en aquella parte los bancos en que los pobres se han de sentar para lavarles los pies y en frente unas mesas largas y bancos para que se sienten a comer y debajo de las mesas las cestas en que se recoge la vianda y al rincón que está entre la puerta de la antecámara y la antecamarilla hay un butete con sobre mesa en que el mozo de la limosna pone el paño para los vestidos de los pobres, y una bolsilla con cada vestido con la limosna ordinaria. También arma la furriera mesas para la vianda en alguna pieza cerca y acomodada y suele servir para esto la que llaman de las cortes, que está de la otra parte del salón de la Guarda. La panetería cubre la mesa de los pobres y pone a cada uno salero, servilleta, cuchillo, cuchara y un pan de boca.

También cubre la Sausería las Mesas en que se pone la vianda en la pieza de las cortes.

Gahcia Memicadal, José, op. cit. vol. Il, pág. 1.265. 
La cava pone a cada pobre sobre la mesa un jarro vidriado de cuatro azumbres de vino y una copa de vidrio en forma de cáliz y tiene alli cerca el Sumiller un jarro de los mismos con agua para echar a beber a los pobres.

La frutería, los principios y adorna la mesa de ramilletes y flores y también provee de ellas para los postres y para el oficio de la panetería.

La vianda la suben del Guardamangier los barrenderos (desde el año de 84 la suben los mozos de oticio y galopines de las cocinas) a las mesas que están en la pieza de las cortes y el potagier la adorna con ramilletes y flores $y$ un oficial de la cocina con portador sube lo que se ha de servir caliente en algunas piezas grandes.

También se suben a esta pieza los postres de la panetería y fruteria.

El mozo de la limosna sienta a los pobres en el banco donde han de estar para lavarles los pies.

El médico de cámara de semana reconoce si tienen alguna enfermedad contagiosa.

El boticario, el mozo de la limosna, el aposentador de palacio y el limos nero mayor los previenen lavándoles primero los pies por la orden que está dicha.

En quedando encerrado el Santísimo Sacramento sale S.M. de la Capilla y viene en procesión con la Cruz hasta la antecámara. Los Mayordomos están con bastones y corre por cuenta del semanero el tener despejado desde la pieza donde está la vianda hasta donde se sirve a S.M.

En la saleta está la guarda de arqueros en orden por un lado y otro y el Teniente y dos arqueros a la cabecera de la mesa de los pobres donde S.M. empieza a servir. En la sala las dos raciones haciendo calle. El diácono vestido canta el Evangelio y S.M. al mismo tiempo se va quitando la capa, espada y sombrero y se ciñe una toalla que le da el limosnero mayor y en su ausencia el Sumiller de cortina, tomándola de mano del mozo de la limosna, y lava los pies a los pobres.

Acabado el lavatorio, mientras S.M. se pone la capa, espada y sombrero (en el año 1755 sirvió S.M. las viandas a los pobres sin ponerse el sombrero) el mozo de la limosna lleva a los pobres a sentarse en la mesa. S.M. empieza a servir levantando los principios que están en la mesa y dándoselos al Sausier que está de rodillas con una toalla ceñida y los va poniendo a cada pobre en su cesta.

En el interín que S.M. levanta los principios al primer pobre van los Gentileshombres de la Cámara por antigüedad por la vianda a la puerta de la pieza donde está y cada uno con su familia trae la de un pobre, entrégasela el Contralor y él la levanta de una mesa cubierta y la va dando a sus criados, quedándose a lo último con dos platos en la mano: viene delante y da estos dos platos, los primeros a S.M. que los pone al pobre para que coma y la demás vianda la va recibiendo de sus criados y dándola a S.M. y el Sausier la va tomando y poniendo en la cesta.

El sumiller de la cava por detrás de las mesas va echando de beber a los pobres. 
En acabando la vianda vuelven los Gentileshombres por los postres y S.M. empieza a servirlos por el primer pobre y cada uno tiene la servilleta y recoge en ella confites y suplicaciones y con el pan, salero, cuchara y cuchillo lo ponen en la cesta.

La paneteria levanta el mantel. Los Gentileshombres van por los vestidos y las bolsas al bufete y lo traen ellos mismos y S.M. lo va tomando y poniendo a cada pobre. El capellán limosnero mayor da las gracias y S.M. se va a comer. Las servilletas, cucharas, cuchillos, cestas, vestidos, toallas y vidriado con que se sirve este día a los pobres y lo que se da a los oficios 10 compra el limosnero del dinero de la limosna" 20.

Sobre la comida de pobres de Jueves Santo existe una gran cantidad de información para el siglo XVIII ${ }^{21}$. Por tratarse de una ceremonia tradicional, que ya venía de la época de los Austrias, y llena de simbolismos religiosos, la tendencia fue conservarla igual, sin apenas variaciones. Tampoco cambiaba su contenido. El banquete de los trece pobres comenzaba con unos principios a base de abundantes y variadas frutas, tanto frescas como secas. Seguía con trece platos de varios pescados, cocinados de diversas formas, a los que se añadían un plato de espinacas rehogadas, con pasas y piñones, y un plato de arroz con leche. En total 15 platos para cada pobre. Para finalizar, de nuevo varios platos de frutas frescas y frutas secas, junto con las tradicionales aceitunas y anises o confites. Todo acompañado de abundante pan y vino, exactamente una libra de pan de boca y una jarra con media arroba de vino, por persona. El menú de la comida del Jueves Santo del año 1747 puede servir de ejemplo:

Vianda que se ha de servir a cada uno de los trece pobres el día de Jueves Santo del año $1747^{22}$.

\section{Platos}

13 de salmón fresco cocido

13 de salmoncillos salados

13 de congrio fresco empanado

13 de merluza fresca cocida

13 de mero fresco asado

13 de lampreas de Holanda empanadas

20 Archivo General de Palacio (A.G.P.). Madrid, Fernando VI, Caja 359.

Vid A.G.P. Felipe V, legs. 158, 268 y 291. Fernando VI, Caja 359. Carlos III, leg. 508.

A.G.P., Fernando VI, Caja 359. 
13 de lenguados frescos fritos

13 de besugo fresco empanado

13 de merluza empanada

13 de congrio cocido

13 de lenguados en escabeche

13 de ostras en escabeche

13 de escabeche de besugo

13 de espinacas rehogadas con pasas y piñones

13 de arroz con leche

\section{Principios}

13 de melones

13 de limones

13 de naranjas

13 de orejones

13 de pasas y almendras

13 de peros

13 de higos negros

Postres

13 de granadas

13 de limas

13 de avellanas tostadas

13 de nueces

13 de esperiegas

13 de dátiles

13 platos de aceitunas

13 de anises

El banquete era generalmente una imagen de la sociedad, de la sociedad ordenada que se expresaba en la jerarquía de la mesa y de la sociedad desordenada cuando degeneraba en orgía o bacanal. La mesa unía y separaba, pues comian unidos los que formaban parte del mismo grupo, pero dentro de la mesa se reflejaban las jerarquías y de la mesa se excluía a los que de manera permanente o sólo temporal se hallaban fuera del grupo o no podian pertenecer a él. El banquete tenía un importante papel de cohesión social, comer juntos indicaba formar parte del mismo colectivo, ya fuese un grupo de cortesanos o un grupo de personas que compartían el mismo oficio o profesión o pertenecian a la misma 
corporación o institución. Muy representativos de los banquetes de consolidación de grupo, clara expresión comunitaria, resultaban las comidas de las cofradías, en las que una vez al año los hermanos se reunian en fraternidad para celebrar la fiesta en torno a la mesa. Por ejemplo, las ordenanzas de la Cofradía de la Transfiguración de Duruelo, que datan de 1566, proporcionan una idea de la preparación y del contenido alimentario de este tipo de festines de reafirmación de grupo, muy representativos del ideal de banquete en la mentalidad popular, centrado en la abundancia de carne:

"Hordenaron que se coma la dicha cofradía el lunes después de San Miguel de setiembre en cada un año. (...) Hordenaron que para la comida que come el dicho cabildo, los oficiales e mayordomo compren dos bueyes, los mejores que se hallaren, e quatro carneros, e sus colaciones como se suelen dar e lo demás necesario para la dicha comida. Hordenaron se maten las vacas el viernes antes e los carneros el sabado. $Y$ el dicho viernes, para matar las vacas aquel dia se de una comida al que las matare, y a los que le ayudaren a colgar los bueyes les den de bever, y no se haga aquel dia otro gasto. $Y$ el sabado los oficiales por su trabajo gasten lo que se suele gastar en pan e vino y el menudo de carnero y una pança de vaca de las que se dan al casero, y se a obligado el casero de la dar por cuarenta maravedies para comer alli. Hordenaron que el lunes de la comida se de de comer despues de haver comido los hermanos en una mesa aparte a los pobres que oviere a la puerta, de los más necesitados que a los oficiales les pareciere e lo hagan con ellos to mejor que pudieren; y si no oviere pobres a la puerta de la cofradía lo embien a sus casas de personas necesitadas, o a la carcel si oviere pobres. Hordenaron que el lunes por la tarde y el lunes después de comer se hagan almonedas de la carne e vino que sobrare e de lo demas necesario, según se acostumbra. (...) Hordenaron que los contadores e alcalde sean obligados el martes luego siguiente despues de la comida a tomar quenta de gasto e rrescibo e provechos del cabildo al mayordomo que saliere e le hazer alcance al cavildo o al mayordomo si le oviere (...). Hordenaron que qualquier cofrade que riñere el dia de la comida o afrentare a qualquier hermano e echare mano a cualesquier armas o a qualquier género dellas, el uno contra el otro dentro del cabildo o a la puerta del estando en cabildo junto a los oficiales o qualquier dellos, pague de pena una comida como aquel dia la come el cabildo. Hordenaron que ningun hermano sea osado a tomar cosa del cabildo, carne ni pan ni vino ni cera ni otras cosas del, si pena que el que lo tomare lo pague doblado lo que valiere de lo que ansi oviere tomado y le echen de pena una colación que se gaste a todo el cabildo, que sea hasta quinientos maravedies, y si fuere oficial pague de pena una comida de pan y vino e carne de hasta seis ducados y no pueda ser más oficial» 23 .

Linage Conde, Antonio, Las Cofradias de Sepúlveda. Segovia, Caja de Ahorros de Segovia, 1986. págs. 109-112. 
Muy interesantes como símbolos de ingreso en un grupo son, por ejemplo, los banquetes de graduación de los estudiantes, que en las grandes universidades alcanzaron una esplendidez exagerada, a la que hubo que poner límites. Un documento de la Universidad de Salamanca, de principios del siglo XVII, de 1619, establecía las colaciones acordadas para las ceremonias de los grados de doctor:

"Collaciones que se an de dar en los doctoramientos que obiere con paseo en las facultades de cánones y leyes y medicina, en virtud de la comission que fue dada a 9 de agosto de 1619 años"

En una caja grande se a de dar lo siguiente:

Una libra de diacitron muy bueno de Valencia.

Una libra de tallos de lechuga.

Una libra de peras de azúcar muy buenas.

Una libra de rajadillo de Portugal.

Quatro roscones de pasta que pesen libra y media, con olor.

Una libra de limas y limones secos de azúcar.

Una libra de confites largos de cidra.

Todo esto a de yr en la dicha caxa. Y encima de ella una caja de perada de azucar, con olor, de cuatro libras.

Collación suelta en las mesas la tarde del paseo para la Universidad:

A cada persona un plato grande y en el:

Dos roscones de pasta con olor que pesen una libra.

Dos ladrillos de carne de membrillo que pesen una libra.

Dos pasteles de pasta con olor y diacitron que pesen una libra.

Media libra de rajadillo de Portugal.

Veinte platos de ensalada a trechos de yerbas, alcaparras, diacitrón, huebos, Ionjas de tocino y azeytunas, y libra y media de truchas en cada plato.

Pan y vino blanco y tinto y aloque.

Azeytunas y la fruta que obiere.

Collacion de toros:

A cada uno su fuente con dos peras de azúcar, media libra de rajadillo, dos taxadas de diacitrón, dos peras verdes o dos camuesas, o dos melocotones, dos mazapanes que pesen una libra, dos vizcochos bañados de azucar con olor.

Vino blanco y tinto y aloque.

Para echar por las bentanas:

Una arroba de confitura ordinaria.

Doce docenas de garrochas. 
Caxa a los que acompañasen a yr a los toros a las bentanas de la Universidad:

A cada uno una caxa pequeña, y en ella una libra de calabazate de. Valencia, una libra de mana, otra libra de almendrones grandes, que son las tres libras que se an de dar conforme al nuevo estatuto.

Collacion a la ciudad y caballeros:

Dieciseis platos de ensalada como la que se da a la Universidad y fruta la misma.

Pan y vino, lo mismo.

A cada persona un plato con los siguiente:

Dos roscones de pasta de azúcar.

Dos ladrillos de azucar de carne de membrillo.

Dos taxadas de diacitron bueno de Valencia.

Media libra de rajadillo de Portugal.

Dos bizcochos bañados de azucar con olor.

Dos peras de azucar que pesen media libra o zermeños ${ }^{24}$.

La alimentación tiene normalmente un importante papel socializador. Aunque nutrirse es un acto individual, alimentarse es un hecho cultural que los seres humanos suelen hacer en común. El banquete es un fenómeno de socialización por excelencia. Una persona puede darse un gran banquete solo, pero seria un caso raro, lo normal es hacerlo en un grupo más o menos grande. La fiesta y el banquete tienen un sentido muy marcado de compartir la experiencia con otras personas y de hacerlo públicamente. La cuestión está en quien comparte con quien y quienes quedan excluídos. Los marginados del banquete son marginados de la comunidad, ya sea un fraile que ha incumplido la regla o un cortesano que ha caido en desgracia.

Salirse de la norma en un banquete, comer hasta hartarse, beber en abundancia, hasta cierto punto era un elemento integrador, todos estaban más contentos, tendían a olvidar los problemas ordinarios, los motivos de discrepancia y división de la vida corriente y parecian sentirse todos más unidos. Podía ser, pues, un signo de confirmación del orden social vigente. La forma de organizar y desarrollar un banquete reflejaba con gran

\footnotetext{
24 Archivo de la Universidad de Salamanca. 784, fols. 79-80. Citado por Rodriguez-San PEdro BezARES, Luis Enrique. La Universidad Salmantina del Barroco. periodo 1598-1625. Salamanca, Ediciones Universidad de Salamanca, 1986, Vol. III. Apéndices, págs. 910-912. Sobre las ceremonias del grado de licenciado y del grado de doctor vid. la misma obra, vol. Il, págs. 744-759 y 782-798.
} 
exactitud la jerarquía existente, tal como se disponía el orden de la mesa y el orden del servicio, la distribución de los alimentos. En un ambiente festivo y alegre el banquete se convertía, y así era entendido y utilizado, en un acto de adhesión al orden establecido. Pero cuando se iba demasiado lejos y la ruptura y transgresión de las normas alimentarias habituales eran graves, el banquete podía acabar siendo un elemento de subversión y de división. La gula, la embriaguez, sobre todo a nivel popular, podian tener un efecto disgregador y llegar a ser elementos de desorden del sistema social establecido. Por ejemplo los banquetes de carnaval fueron con frecuencia fiestas típicas de la transgresión, que solían terminar en una bacanal.

El banquete era en la época moderna, como en otras, una de las formas consagradas de celebración y los motivos y circunstancias podian ser muy variados. Banquete equivalía con frecuencia a tradición, como se evidenciaba, por ejemplo, en Navidad. Lo apropiado era comer repetidamente, año tras año, algo especial, lo que se comía aquel día y no otro, convirtiendo el alimento en referencia cultural, signo de la memoria colectiva. En Navidad lo típico eran las piezas de volatería rellena, las «neulas» y los turrones. En Pascua de Resurrección el cordero asado. Pero el banquete era también innovación. Los banquetes de boda de la nobleza catalana de la segunda mitad del siglo xvIII que relataba el Barón de Maldá eran banquetes diferentes, a la francesa, como signos de refinamiento y modernidad. Era un elemento de prestigio presentar algunos platos nuevos, mucho más si se trataba de platos extranjeros, procedentes de una gastronomía triunfante como era entonces la de Francia. Sin embargo, la tensión entre tradición e innovación siempre existió y configuraba diversas actitudes. En esa misma época, un nuevo rico como Erasmo de Gónima hacía ostentación de su riqueza y de su encumbramiento social en banquetes a la francesa. En cambio, otros criticaban las nuevas modas, como hacía Cadalso en los Eruditos a la violeta ${ }^{25}$. El banquete era también utilizado como elemento de fijación de la identidad y la memoria colectiva de un pueblo o de un grupo concreto y así se recurría a ellos para festejar actos importantes de la vida de una persona y de una familia, conmemorar un pacto en comunidades campesinas, celebrar las fiestas mayores de los pueblos, las fiestas de gremios y cofradías en los días de los santos patrones, los exámenes y el momento de acceso a un nivel superior de los estudios o del oficio y los actos oficiales en las más diversas instituciones.

25 Pinto, Mario di, "Un pranzo «a la violeta”, en Profeti, M. G. (ed.), op. cit., págs. 313-337. 
Los tiempos de la alimentación festiva, como los de la alimentación ordinaria, respondian, pues, a motivaciones muy variadas. Era fundamental el ritmo de la naturaleza, al que el hombre de la época difícilmente podía escapar, dados los precarios niveles tecnológicos. Se imponía el ciclo estacional, primavera, verano, otoño e invierno, pues de él dependían la mayoría de los productos vegetales y animales. Estrechamente relacionado se hallaba el ciclo agrario, con una serie de etapas, como la sementera, la cosecha, la vendimia. También dependía del ritmo de la naturaleza y de la vida campesina un ritual tan importante y extendido como era la matanza del cerdo. Al ciclo de la naturaleza se superponía el ciclo litúrgico y festivo establecido por la Iglesia y la tradición, que en una época de honda religiosidad marcaba con su impronta el transcurrir del año en todos los sentidos, incluído el alimentario. Adviento, Navidad, Reyes, Carnaval, Cuaresma, Pascua, Corpus, fiestas patronales, Todos los Santos eran tiempos y dias en que la alimentación variaba en cantidad, se comía mucho en Navidad, Carnaval y Pascua y menos en Cuaresma o en Adviento.

Navidad era una de las celebraciones alimentarias más sobresalientes y significativas, que todos, desde los más altos a los más bajos, trataban de festejar. Francisco Martínez Montiño, cocinero de Felipe III y de Felipe IV, presentaba en su Arte de cocina, pastelería, vizcochería y conservería, varios menús de fiesta y entre ellos un banquete de Navidad con el siguiente espléndido menú:

\section{"PRIMERO}

Perniles, con los principios.

Ollas podridas.

Pabos asados con su salsa.

Pastelillos Saboyanos de ternera ojaldrados.

Pichones, y torreznos asados.

Platillo de Arteletes de aves sobre sopas de natas.

Bollos de vacia.

Perdizes asadas con salsa de limones.

Capirotada con solomo, y salchichas, y perdizes.

Lechones asados con sopas de queso, y azúcar, y canela.

Ojaldres de masa de levadura con enxundia de puerco.

Pollas asadas.

\section{SEGUNDO}

Capones asados.

Anades asadas con salsa de membrillos.

Platillo de pollos con escarolas rellenas.

Empanadas Inglesas.

Ternera asada con salsa de oruga. 
Costrada de mollejas de ternera, y higadillos.

Zorzales asados sobre sopas doradas.

Pastelones de membrillos, y cañas, y huevos mexidos.

Empanadas de liebres.

Platillo de aves a la Tudesca.

Truchas fritas con tocino magro.

Ginebradas.

\section{TERCERO}

Pollos rellenos con picatostes de ubres de ternera asados.

Gigotes de aves.

Platillo de pichones ahogados.

Cabrito asado, y mechado.

Tortas de cidras verdes.

Empanadas de pabos en masa blanca.

Besugos frescos cocidos.

Conejos con alcaparras.

Empanadillas de pies de puerco.

Palomas torcaces con salsa negra.

Manjar blanco.

Buñuelos de viento.

Las frutas que se deben servir en esta vienda, son:

Uvas, melones, limas dulces, ó naranjas, pasas, y almendras, orejones, manteca fresca, peras, y camuesas, aceytunas, y queso, conservas y suplicaciones" 26 .

Un siglo más tarde, en el XVIII, y en un escalón no tan alto, los menús del Barón de Maldá para las fiestas navideñas constituyen también un buen ejemplo, marcados fuertemente por la tradición, que se seguía fielmente año tras año. Platos típicos, comidas abundantes y largas caracterizaban la fiesta. El 25 de diciembre de 1786 escribía el Barón de Maldá:

«Per tal diada de Nadal se mengen en les taules de senyors i de molts menestrals, galls i polles ab farciment, i en taules d'artistes, marxants etc. com també, per postres, torrons i neules ab vi blanc o malvasia i demés festes de $\mathrm{Nadal}{ }^{27}$.

El 25 de diciembre de 1796 se repetía la escena alimentaria:

Mahilinlz Montino, Francisco, op. cit., págs.13-15

BARO DE MAL DA, Calaix de Sastre. Barcelona, Curial, vol. I, 1769-1791, 1988; vol. II, 1792 1794, 1987; vol. III. 1795-1797, 1988; vol. IV, 1798-1799. 1990; vol. V, 1800-1801, 1994; vol. VI, 1802-1803, 1994; vol. VII, 1804-1807, 1994; vol. VIII 1808-1810, 1996. Vid. también del mismo autor Exili de Barcelona i viatge a Vic (1808), Publicacions de l'abadia de Montserrat, 1991. Para esta referencia vid., vol. I, pág. 166. 
"No ha impedit a la gent en los dos sexos, de tota classe, edat i estament, ab tot de no haver-se vist lo sol, d'anar als acostumats passeigs de muralles i Rambla, majorment en aquest dia, per pair lo gall i polla d'índia, ab tot son farciment, capons rostits i polles, torrons i neules sucades ab garnat$x a$, vi blanc o malvasia; solent fer los més alguna extraordinari, principalment los que poden gastar» ${ }^{28}$.

El 25 de diciembre de 1801 de nuevo se presentaba el mismo panorama:

"Avui és dia que tothom desitja traure sa panxa al sol, ano quedar amagat, per tenir-la ben plena de perdius, capons, galls i polles d'India (...) no he trobat la confusió de gent que em pensava a tres hores tocades, ni cotxes. I seria alguns senyors i senyores no haver encara acabats de dinar, sucant neules, después de menjar los torrons, ab vi de Màlaga, vi blanc 0 garnatxa» ${ }^{29}$.

Las clases populares del campo y la ciudad, en la medida de sus posibilidades, trataban de celebrar también la Navidad con algún extraordinario, procurando que no faltaran los productos tradicionales, algún pollo, "neulas" y turrones. Estas referencias festivas no estaban ausentes ni siquiera en la mesa de los más pobres, por ejemplo los niños huérfanos asistidos en la "Casa d'Infants Orfes" de Barcelona comían estos productos típicos en las fiestas navideñas, según revelan los libros de cuentas de esta institución en la época moderna ${ }^{30}$.

El Carnaval era otro de los tiempos festivos en que la alimentación cobraba importancia. Se comía mucho y se comía bien, como preludio a los largos dias de ayuno y abstinencia de la Cuaresma. Carnaval, que quiere decir exactamente despedida de la carne antes de entrar en un período penitencial de privación, es la fiesta popular por excelencia, con un fuerte contenido de subversión y de crítica de la sociedad ordenada y establecida. Era un espectáculo de masas en el que todos participaban y que tenía lugar fundamentalmente en público, pues en la calle se bailaba y se comía. Según una relación del Carnaval de Barcelona de 1616, los actos principales tuvieron lugar en la calle Ample y en el Born y el banquete popular se celebró en la calle de la Palla, donde estaba situada la larga mesa llena de mantecadas y pasteles, huevos y queso, platos de carne picada

MAL.DA, op. cit., vol. III, pág. 168.

Ibidem, vol. $V$, pág. 280

30 Arxiu Capitular de la S.E. Catedral Basilica de Barcelona. Casa dels Intans Ortes. Periodos consultados: 6 Administració XII Rebudes i despeses de menut, 1551-1555. 9 Administració XIII, Llibre de les entrades i Eixides, 1651-1652. 9 Administració, XIII, Llibres d'entrades i d'eixides, 1753-1773. 
de carnero y pies, carnero hervido y asado, cabrito, volatería, arroz y fideos a la cazuela ${ }^{31}$.

En el siglo XVIII la celebración del Carnaval continuaba siendo importante, a pesar de la voluntad de control por parte de las autoridades y de una relativa privatización de la fiesta. Se organizaban grandes bailes y saraos, en los que el banquete ocupaba un lugar destacado. Las gentes se dedicaban a comer hasta hartarse, tanto en casa como fuera de casa, en los cafés y tabernas, pues entregarse a la gula formaba parte del festejo. Era cuestión de marcar el contraste entre la abundancia del Carnaval y la austeridad cuaresmal. Los platos típicos del Carnaval eran platos de carne, sobre todo volatería y cerdo, ya que la carne estaría ausente de la mesa en los siguientes cuarenta días, y una vez más se quería marcar el contraste, disfrutar de la carne, a poder ser hartarse de ella, antes de entrar en los dias de abstinencia. A esta exaltación de la carne contribuía la proximidad con las fechas de la matanza del cerdo, que tenía en Carnaval una marcada presencia. El Carnaval simbolizaba el triunfo de la carne y de la grasa. También se comían algunas antiguas especialidades dulces, como el manjar blanco y las cocas de chicharrones.

El Calaix de Sastre del Barón de Maldá constituye igualmente una interesante fuente de información. En Cataluña el plato típico por excelencia del Carnaval, plato que el Barón de Maldá insistía en calificar de catalán, era la cazuela de arroz, con pies de cordero o cerdo, lomo, tocino y butifarra, cubierto con huevo, azúcar y canela. En el plato, además de su contundencia, destaca la mezcla de sabores, salado y dulce, tan característico de la gastronomía catalana de la época. El 20 de febrero de 1792 escribía el Barón de Maldá:

"Avui, dilluns de Carnestoltes, sol ser dia de descans d'alguns saraus; però en quant a uns bons gaudeamus en taules, de cassoles d'arròs, capons rostits i plates de menjar blanc, penso que en moltes se n'hi mengen, en estos cinc dies de Carnestoltes, des del dijous llarder" ${ }^{32}$.

$Y$ al día siguiente insistia en el tema, comentando el gran trabajo de las tabernas y fondas, que servian continuamente comidas y bebidas: "Les tavernes i fondes, cop de despatxar vi, i polles, capons etc., fins a quarts de dotze de la mitjanit» ${ }^{33}$. Varios años más tarde, durante el Carnaval de

\footnotetext{
GRILLI, G., «Excés d'oralitat i carnaval a la cultura urbana entre manierisme i barroc». Estudis de llengua i literatura catalanes, VI, 1983, págs. 309-357.

3 MALDA, op. cit., vol. II, pág. 11.

33 Ibidem.
} 
1797, el 26 de febrero, repetía las mismas ideas, abundancia de comida, en casa y fuera de casa, presencia destacada del plato típico de la cazuela de arroz:

«... bucòlica en abundància en les fondes, cafès, cases i tavernes, de capons, polles i demés volateria, solent-se menjar en est temps lo famós plat català de cassola d'arròs ab porció de peus de crestat i moltó, botifarra ab crosta d'ou i sucre, que és plat d'allò ben regalat, per lo substanciós, dolç o llaminer que és. I a mi que em sap també molt bona dita cassola d'arròs, ab tot lo que hi entra" ${ }^{34}$.

La comida típica de Carnaval se repetía año tras año y el Barón de Maldá la anotaba, precisando las ligeras variantes, que ilustran cumplidamente sobre las diversas especialidades alimentarias de la celebración. En el Carnaval de 1802, el 2 de marzo, escribía:

"Avui he tingut l'amable companyia, en la taula, per menjar tots - ab mossèn Domingo Vernet-, de la marquesa de Castellbell, la cassola d'arròs ab peus, cansalada i botifarra - despido d'esta per aquest any- ab los demés "ultres" recreatius i llaminers al ventre, com la crema de llet, a postres, i coques ab llard. I per saber a festa d'innocents, quarta de Nadal, hem sucat algunes neules a un poc de vi de Màlaga, celebració de dimarts de Carnestoltes..." ${ }^{35}$.

En el Carnaval de 1803, el 17 de febrero, la historia se repetía:

«En quant a la bucòlica, és en les taules dels senyors i demés que poden gastar i tenen bon gust los substanciós i ensucrat plat de cassola d'arròs i de peus, llomillo i botifarra, ab crosta d'ou, sucre i canyella. Aixi també coques de llard i plats de menjar blanc; que en lloc d'anar a sarau de carnaval, és lo carnaval la bucòlica del plat català de cassola d'arròs ab tot lo demés que tinc referit; i est també és mon carnaval, sí que no volent-ne de res d'això massa atipar, per lo que seria gola, i, sent la gola lo quint dels pecats mortals, se deu evitar, com aixi tots los demés vicis, que degeneren a l'home del ser cristià i de racional» ${ }^{36}$.

Para el Barón de Maldá la verdadera celebración del Carnaval consistía, más que en los bailes de máscaras, en la famosa cazuela de arroz. Por ese motivo se lamentaba el 20 de febrero de 1803, domingo de Carnaval, ante la falta del típico plato en su mesa, pues además de ser un 
plato muy de su agrado, su ausencia representaba una quiebra imperdonable de la tradición:

«... los i les que corren saraus i tarumbes en est temps de carnaval; com així jo, que faç ab mà família mon carnaval en casa, menjant alguna cassola d'arròs. Sols que avui, diumenge de Carnestoltes (error garrafal), se n'ha olvidat de fer-ne la cuinera; i l'excusa: per no tenir peus de moltó, o de crestat; i lo que sobra són peus, i que ab arròs i crosta d'ou ab son sucre, i canyella, hauriem conegut més en la taula ser diumenge de Carnestoltes. I lo que sempre s'ha fet aixis, no sent mal, no deu variar" ${ }^{3}$.

En Carnaval no todo se reducía a la cazuela de arroz. En muchas casas se organizaban comidas, meriendas y cenas, con menús muy suculentos y variados. El 19 de febrero de 1798 el Barón de Maldá y su familia fueron invitados a una espléndida merienda-cena:

«En casa Vega, en l'entrada de nit, convidats tots nosaltres allí a berenar, en celebració de Carnestoltes. Se servi en taula parada, ben il.luminada, adornada d'un petit ramillete al mig, ab garrafes de cristall de vins, i altres d'aigua, ab moltes viandes de capons rostits, anyell, empanada de colomins, tortrades de llet, cremes, ous filats ab talls de poncem, i altres llepoleries d'estes, ab dos formatges gelats, hetxures de sombreros d'orinal, un de llet $\mathrm{i}$ altre de taronjada. Un berenar i, juntament, sopar; recreatiu tot allò a la vista, i més al gust" ${ }^{38}$.

También era importante desde el punto de vista alimentario el ciclo vital, ligado directamente por las mismas razones de religiosidad al ciclo sacramental eclesiástico: nacimiento y bautismo, matrimonio y boda, muerte y funerales. Cada una de estas ocasiones trascendentales de la vida del individuo y de la familia se solían celebrar con festines, que a veces incluian determinados alimentos tradicionales ${ }^{39}$. Las bodas eran los festejos alimentarios más sobresalientes y todos los grupos sociales trataban de celebrarlos de la manera más espléndida que sabían, gastando con frecuencia más de lo que era razonable y hasta posible para sus economías. Los banquetes de boda eran uno de los ejemplos más característicos de abundancia. El refinamiento no estaba siempre garantizado y dependía de la calidad de los novios y también de los gustos. Baste recordar las famosas bodas de Camacho del Quijote. De la misma época, aunque más

lbidem, vol. VI, pág. 185.

Ibidem, vol. IV, pág. 22.

Sobre las comidas de entierro vid, por ejemplo, el interesante trabajo de LOPEZ LOPEZ, Roberto J., Comportamientos religiosos en Asturias durante el Antiguo Régimen, Biblioteca Histórica Asturiana. Oviedo, Silverio Cañada, ed., 1988, págs. 76-78. 
desconocido, pero también enormemente interesante, es el menú de un banquete de boda, compuesto por comida y cena, organizado por una acomodada familia campesina catalana, de la comarca del Solsonès, que nos ofrece un documento de principios del siglo XVII, el memorial del convite de Antoni Pallarés para la boda de su hijo. El menú de la comida constaba de los siguientes platos: "Posar de dos en dos un plat ab una cuherna de regells de ginebre vert y un altro plat al custat $(a b)$ una cuherna de talades de pinyonada de sucre, y devant una tassa ab una de vi." Después de haber comido y bebido, se disponía que retirasen los platos: «... y posar los torqueboques y los ganivets aprés lo ha, y posar aixi mateix un plat de rehims de en dos, y darlos a beure vi blanch". A continuación volvían a cambiar los platos y ponían: "un plat de cansalada de sucre, de dos en dos, donarlos a veure claret si tenen." La culminación del banquete era verdaderamente consistente, con asados y olla, destacando al final los postres dulces: "Aprés los plats de capons en ast an salsa de Pagó. Aprés los plats de gallina en olla ab lo menjar blanch, o, si no hi ha menjar blanch, fer algun potatge de rovells ous ab sucre e canyella y aigua ros. Dat que es això les posades del porcell ab oruga. Aprés algunes posades de moltó en olla. Levat tot aixó darlos suplicacions o neules de sucre ab iprogues... darlos una posada de dregea ab algunes tasses de malvesia". La cena consistía en lo siguiente: "Entretant, lo ensiam ab anxoves y olives y taperes y altres coses que se acostuma en dit ensiam. A beure vi xinell. Aprés de dos en dos dar un plat dels caldums de les gallines. Aprés una perdiu per persona. Aprés algunes posades de cabrit $a b$ oruga. Aprés alguna posada de cuixes de moltó ab son suc. Si es podrien dar algunes formatjades o flahons ia no cabria més fins los plats de torrons picats ab vin blanch. Aprés bocins dregea y aprés rentar les mans" ${ }^{40}$.

En el caso de la nobleza el festejo de las bodas llegaba a su máxima expresión, pues reunía toda una serie de convites de gran categoría. Generalmente se celebraba durante tres días, con comidas, cenas y refrescos de gran lujo. Llegaba un momento en que a los invitados apenas les era ya posible comer más. Pero el despliegue de medios se mantenía a pesar de todo, pues era una cuestión de prestigio y de tradición, que no podía dejar de respetarse. El Barón de Maldá en su Calaix de Sastre relata con gran detalle y preciosismo varias bodas, que ilustran muy bien sobre el tipo de alimentación, adornos y maneras ligadas al acontecimiento. Por tratarse de celebraciones sociales, la decoración cobraba una importancia grande, destacando la fantasía de los ramilletes que adornaban

40 Museu Diocesà de Solsona. Arxiu Pallarès. Siglo XVII. 
las mesas y el lujo con que éstas eran puestas, con vajillas - habitualmente de cerámica y tratándose de familias muy ricas de porcelana-, cubiertos - generalmente de plata y a veces de plata sobredorada-, manteles y servilletas de la mejor calidad.

Más que una comida era un escaparate, que buscaba manifestar la riqueza y honor de la familia y asombrar a los convidados. Trataba de complacer tanto el gusto como la vista. La abundancia era tan grande que rozaba la exageración y la excelencia superaba lo habitual. Cada comensal podia elegir entre la multitud de platos presentados, de acuerdo con su apetito y con su gusto. De todos modos llegaba un punto en que los comensales de estos banquetes, desbordados por la cantidad y la calidad de los manjares, tenían que renunciar a consumirlos y debian contentarse con admirarlos.

Las comidas, dispuestas al estilo francés, eran de aparato, con varios servicios, generalmente tres, que cubrian sucesivamente la mesa. Había gran cantidad de platos, a veces centenares, salados y dulces, que eran especialmente abundantes, variados y refinados. El primer servicio o simetría era el más sólido, a base de sopas, olla, macarrones. El segundo compaginaba los platos de volatería - capones, pollos, pavos-y los de carne, con los de pescados y mariscos de calidad. Además se añadían platos considerados delicados y exquisitos, salados y dulces. El tercero era el de los postres dulces, los helados y las confituras. Se bebia agua y vino, a veces solo y a veces mezclado con agua.

Era costumbre novedosa de la época terminar el banquete con el café. Generalmente se servía en una sala aparte, con el fin de permitir un tiempo de descanso y sobremesa. Para servirlo se disponía de una vajilla especial, con platos, tacitas y cucharitas, diseñados para ello. El café se tomaba solo o con leche, a gusto del consumidor, y se endulzaba con azúcar, en mayor o menor cantidad, también según los gustos particulares. Es interesante constatar la moda del café, que empezaba entonces tímidamente a hacerle la competencia al producto rey, que era el chocolate. Resulta especialmente interesante señalar la introdución del café, asociado a la sobremesa de banquetes celebrados en festividades de gran relieve, como eran las bodas y otros acontecimientos similares. Además de considerarlo un placer, al café se le atribuían virtudes especiales para ayudar a hacer la digestión de tan desbordantes festines. En ocasiones se completaba el café con licores, como el marrasquino.

Una boda sonada fue la del hermano del Barón de Maldá, don Felip Amat, embajador del Rey de España en Malta, con la señora doña Eulàlia Desvalls i de Ribes, hija del Marqués de Llupià. El matrimonio se 
celebró el domingo 16 de julio de 1797, a las nueve y media de la mañana, en el oratorio de la casa del Marqués de Llupià. Al mediodía se dio un banquete:

"Lo dinar ha estat delicat i ab molta propietat, tant en viandes com en simetries ben posades, ab un ramillete al mig, ab figures d'estuco o màrmol, flors i altres figurilles, ab un ben figurat sortidor al mig. (...)

De substància a fe és bona substància, la sopa ab purea, l'escudella de macarrons, que tot est principi ja començava a hom a omplir-lo per no poder passar avant a més substància. D'esta era la vaca, lo moltó, la vedella, llagostes i llagostins. I, abotxornat hom del calor de la corrent estació i de tot quant entrava a la boca, l'obligava a fer-se omplir tot sovint la tassa d'aigua i vi. Què diré de les postres, si que delicades totes elles d'amargs, ametlles ab granissada o anisades, pistatxos, compotes, almivars i vàrios altres dulces, fruites de peres, formatges, gelats i demés retahila de golosines, que ja no servien les més per lo gust de la llengua, sí que per lo de la vista, per haver-se ja acabades les ganes; terminant ab los codores en veires de vins de Calella i de Màlaga. I per final del gaudeamus en la taula, en l'estrado im. mediat, en escudelletes expresses, ab sos platets i culleretes, café, ab llet i sense, al gust de cada qual, i terrosset de sucre, que qui li agràdia el dolç n'hi sol carregar més.

En fi, ha eixit hom de taula d'allò ben complert, satisfet i ben suat; allò de "fructus ventris generosi". Un cert descuit hi ha hagut en taula, que ha començat ab benedicció i no s'ha acabat lo dinar ab les gràcies; no estilant-se tampoc vui dia en les grans taules lo d'hom rentar-se i eixugar-se les mans, antes i después del dinar, sí que glopejar ab tassa ab aigua tèbia i tovalló, introduint-se de dia en dia més l'ús francès del sans façon" " ${ }^{41}$.

El elemento de fantasía continuaba existiendo en los banquetes del siglo XVIII. El 11 de diciembre de 1798 se celebraron una dobles bodas especialmente importantes para el Barón de Maldá, las de su hijo primogénito y heredero Rafael Maria con Poneta Vega y las de su hija Maria Escolàstica con el joven Marqués de Castellbell. Al mediodía del segundo día se celebró un banquete, con la mesa dispuesta con todo primor. La comida contó con una sorpresa espectacular, un pastel relleno de pajaritos vivos, reminiscencia lejana de aquellos maravillosos y deslumbrantes aparatos a los que fue tan aficionada la baja Edad Media y la primera Edad Moderna:

"Est fou ab tota la possible simetria en les tres escenes, com de teatro: sèria, bufa i entremès, vull dir substància, orduvres, i dolçaina en la primera. En la segona, un mixto de substància i de llepoleria. En esta segona lo gra-

4: MaLda, op. cit, vol. III, pág. 213. 
ciós plat d'un pastel ab presoners dintre -i altre pastel més gros sens estos-, que isqueren a taula; i de tals presoners, fora d'un o dos, ningú sabia res. I aquí era la bulla en lo dinar puix que, havent-se separada un poc la coberta del pastel, esta anà fent moviment obrint los tals presoners una a modo de porteta, traient lo cap fins a eixir-se'n del pastel, volant per la taula i galeria fins a quatre aucelles, que eren verdums (...); que fou pensament aquell dels aucells dintre del pastel d'allò ben cèlebre, i bona humorada del qui li passà tal pensament pel cap (...). En la tercera simetria foren postres, ensucrades les més, bescuits, melindros, ampolles de vins generosos, garrafes d'aigua i vi..." ${ }^{42}$.

El 19 de febrero de 1802 se celebró en casa Planella la boda de los jóvenes condes de Llar. La comida fue de treinta cubiertos. Una vez más la abundancia y la variedad caracterizaron el banquete. En esta ocasión el Barón de Maldá especifica con mucha precisión el menú, compuesto de tres servicios:

"Lo dinar —ab ramillete al mig i simetria - ha començat a molt a prop de dos quarts de tres de la tarda, (...) en prova del prou tarde que vui dia se dina en semblants convits de boda (...); començant a desordenar, sentats a la vora de la taula, la primera simetria de plats forts: de sopa; macarrons ab formatge rallat, que en semblants convits sempre hi sol entrar; l'olla ab vaca, tocino, cansalada, pernil, gallina, verdures i salsa, esta de tomàtec, i l'altra, de mostassa, que per tan rabiosa de coenta - per lo que pica fort al nas i als ulls, a pendre-se'n un xiquet massa a la cullera- s'ha deixat a esta per la salsa de tomàtec, que és molt més moderada; cap de vedella; perdius ab suc; cervellets; pastelets etc.; que, a carregar-se ja un xiquet massa lo ventrell de tota aquella substància, comença hom ja a bufar per causa d'estar ja un xiquet tip. Después d'esta simetria ha seguit la segona, també de prou fartalència, en pavos, capons rostits i ab fiambre; pastels; tortrades; budens; cremes; mantequilles de Sòria; llagostes i altres peixos, tot ab abundància. Així també l'aigua i el vi, que era d'Alella, per lo que tot sovint se vaciaven a les tasses i d'estes quiscun coll avall a l'aduana o oficina del ventrell. Amigos, los ventres ja estaven com uns timbalets antes de les postres. Estes han consistit en formatges gelats de llet i ou, i de taronja; vàrios almivars en confitures; anissos de papabenet, amargs, melindros, bescuits d'ou per sucar en veires en vins de Màlaga i altres generosos; brindant tots a la salut dels nuvis, pués que per ells se feia la festa» ${ }^{43}$.

El 1 de julio de 1802 se celebró la boda del conde de Cancelada con Manuela Peguera, en la torre del Virrey, cerca de Gracia. La comida, que el Barón de Maldá relata con bastante detalle, fue obra de un cocinero famoso entonces en Barcelona, sucesor de otro que también lo había sido,

\footnotetext{
42 Ibidem, vol. IV, pág. 131.
}

43 Ibidem, vol. VI, págs. 26-27. 
se trataba del yerno de Maurici. Los platos fueron muchos y variados, comenzando por la sopa, la olla y los macarrones, siguiendo con carne, volatería y pescados y terminando con postres dulces variados:

"Hem començat a obrír fonaments en la boca, i dret al ventre, escalfant-lo bé ab lo plat de sopa de pulea, que era delicada, de la que hem menjada, i lo plat de macarrons, que quins n'hauran menjat hauran sabut quin gust tenien, mes no jo, per no haver-ne provat siquiera un macarró. Después ha seguit la carn d'olla, de moltó, vaca i verdures molt gustoses, botifarra i cansalada, d'esta que n'eren talls i mig. En seguida, un plat de calamarsos al suc, gran cosa; plat de perdius, que s'estimen molt en una taula en estos temps que no en pot haver qui en vol, per lo ben buscades; altres peixos ben amanits, com palomida, llobarro, i l'escollit plat de llagostins ab herbetes, oli i vinagre. Rostit, crema, budín, un com turbant de bescuit d'ou, postres de vàrios amargos, dulces, formatges, gelats, etc., etc. Vins licorosos per brindar tots a la salut dels nuvis, condes de Cancelada, i cafè a l'últim, ab sucre terrossat, i un poc de marrasquí en altra peça del dinar " ${ }^{44}$.

Si cualquier comida que reuniera familiares y amigos era motivo de satisfacción y alegría, mucho más una comida de bodas, que celebraba un acontecimiento especialmente feliz. Los banquetes solían ser muy animados, hasta bulliciosos. Como escribía el Barón de Maldá con motivo de las dobles bodas de dos de sus hijos en 1798: «No faltà prou bulla en taula, com que de lo contrari no fóra dinar de bodes" ${ }^{45}$. En ocasiones, cuando la celebración sobrepasaba el círculo privilegiado y adquiría carácter popular, la animación subía de tono y terminaba con agitadas «batallas" de confites y peladillas. La abundancia de comida alegraba el ambiente: "I com panxa plena fa bullícia, tothom estava d'allò ben alegre en taula..." ${ }^{46}$. Y sobre todo la generosa presencia de bebidas alcohólicas favorecía la animación y el bullicio: «...tothom alegre; i més ab los vins d'aquelles garrafes i ampolles de l'Antonet, que infundien major alegria a tots los convidats, i més en cosa de bodes, que no hi entra tristor alguna" ${ }^{47}$.

En la boda de Gertrudis Parellada con Pere Pujades el 15 de octubre de 1797, mientras en la planta noble de la torre Castellbell de Horta se celebraba la comida destinada a los invitados principales, en el piso bajo tenia lugar una celebración más amplia, que, con gran disgusto del Barón de Maldá, degeneró en expansiones festivas descontroladas, de una cierta violencia, fruto tal vez de un exceso de consumo de vinos y licores:

44 Ibidem, vol. VI, págs. 75-76.

45 Ibidem, vol. IV, pág. 128.

Ibidem vol. VI, pág. 213.

Ibidem, vol. IV, pág. 137 
"En nostre inter del dinar era a baix lo del bodori de Tuietes ab Peret. No sé si passar de setanta los convidats en los dos sexos. I bulla de borratxos fou la de tirar-se ab tota la força uns a altres ametlles cobertes a la cara, confits i àdhuc alguna poma barrejada, que no deixaren de trencar algun got. Bulla, esta, d'allò ben pesada, en semblants bodes; sent la gala d'estes fer trencs i contusions als qui no en tenen, i pobre del qui Ii peguen a l'ull, per quedar-se sols ab un finestró obert com lo senyor oficial való don Manuel Grancur» 48 .

La boda alcanzó por la noche una dimensión popular, con la participación de campesinos y menestrales, en una cena abundante y animada, que terminaría con la tradicional "batalla» de confites y peladillas:

"Lo sarau començà no sé si a nou hores; i ja fou sarau per diferent terme, ab tanta música de plats, culleres i forquilles, lo sopar de tanta gent, baix, en I'habitació dels nuvis, ab tantes taules de pagesos i pageses, mossos i menestrals, que semblava una fonda. Visitats de nosaltres $i$ altres, contemplantlos com sopaven $i$ alguns confits $i$ atmelles cobertes $i$ de torrades que es tirarien uns als altres, no perdonant a dones, a postres. La cuina pareixia un caos, o confusió, anant totes les casseroles, olles i plats en renou, per afartar a tanta gent com alli hi havia" ${ }^{49}$.

El Barón de Maldá, cuando quería referirse a un gran banquete, decia que era una comida de boda o de fiesta mayor. Las fiestas mayores eran para él ocasión de disfrutar de un buen festín. Asistía regularmente a varias de ellas a lo largo del año, especialmente a las de aquellos pueblos en que la familia poseía alguna casa. Además de asistir a las celebraciones religiosas y a los bailes, su principal interés estaba puesto en las grandes comidas tradicionales, con que se festejaban a lo largo del año los días de los patrones de los diversos pueblos. Al igual que sucedía con las grandes fiestas del calendario litúrgico, las comidas de las fiestas mayores solian estar apegadas a la tradición y respondian con frecuencia a un ritual de productos y de platos bien establecido y que se perpetuaba año tras año.

Como sucedia con otras fiestas, también las fiestas mayores tenían un carácter integrador, pues igual que las ceremonias religiosas y los bailes eran compartidos por todos los vecinos del pueblo y muchos forasteros, de toda condición, todos o casi todos organizaban una gran comida y en ella los platos típicos eran consumidos por todos los grupos sociales. Para las clases populares representaba un gran extraordinario, cuya abundancia y calidad sólo podian permitirse contadas veces a lo largo del año, sumán-

48 Ibidem, vol. III, pág. 259.

44 Ibidem, vol. III, pág. 269. 
dose a ello la tradición de determinados platos, que no podían faltar en la mesa en aquella fecha. Para la nobleza representaba también un extraordinario, en comparación con su alimentación ordinaria, pero teniendo en cuenta que los extraordinarios, tanto en abundancia como en calidad, eran mucho más frecuentes, el énfasis se ponía en la particularidad de los platos típicos, aunque no se reducían a ellos y ni siquiera siempre los incluían en la comida.

La fiesta mayor predilecta del Barón de Maldá era la de Esplugues, que tenía lugar el día de San Mateo, el 21 de septiembre, aunque según en que día de la semana cayera la fiesta, solía ser trasladada al domingo inmediato. La familia Amat la celebraba en la torre que poseía en el pueblo, por todo lo alto, con un espléndido banquete para gran cantidad de invitados. El menú básico típico de una fiesta mayor, bien sustancioso por cierto, se componía de los siguientes platos: "plat de la sopa ab algun calabre", "plat de macarrons o escudella d'arròs i fideus", "plat de la carn d'olla", "plat de relleno de préssecs", "plat de fricandó", "volateria", "empanada", "rostit» y después postres ${ }^{50}$. Plato muy característico de la fiesta mayor de Esplugues, siempre presente ese día en las mesas de las gentes del pueblo y que casi cada año se preparaba también en casa del Barón de Maldá, era el "plat de bou i arròs, sucre i canyella». En casa del Barón de Maldá era también costumbre presentar un plato de melocotones rellenos de carne, también dulce, que era muy del agrado de Don Rafael y al que llamaba "el plato de casa Cortada". Al parecer, estos dos platos también figuraban, en ocasiones, en el menú de las fiestas mayores de otros pueblos, por lo que se les podría considerar platos típicos de fiesta mayor en la Cataluña de la época. Además se servían otros muchos platos variados, la gran mayoría de carne, sólo en ocasiones se incluian mariscos, como langosta, langostinos, ostras, o algún pescado. De postre fruta fresca de la temporada y algunos platos de dulce. El resultado era un gran banquete, con muchos y exquisitos platos. Al final, como en los banquetes de boda, se servía en ocasiones café.

El 25 de septiembre de 1796 el Barón de Maldá hace un relato muy expresivo y pormenorizado del acontecimiento. Comenzaba por describir la preparación de la mesa:

"S'ha parada la taula pel gaudeamus, i que tothom ja tenia les dents ben esmolades. Com hi teniem persones d'alto bordo, s'ha procurat la propietat possible en l'aparato de tovallons, plegats de certa manera en los

5i. Ibidem, vol. I, pág. 283 
plats, i en quiscun, amagat, un pa de crostons, ab sa cullera, forquilla i ganivet; tant los tovallons com les estovalles de roba de domàs o ginesta, $a b$ les ampolles d'aigua i vi al davant, i sos cubos de pisa per cada u, per tenir lo got; servint-se un mateix l'aigua i el vi, per no tenir que cridar al criat per beure» ${ }^{5 !}$.

Después continuaba explicando con detalle la composición de los tres servicios que integraban la comida. El primer servicio estaba formado esencialmente por la olla, "escudella» y "carn d'olla». Para acompañar había melón:

"S'han anat posant los plats ab simetria en taula, i les soperes de pisa per la sopa i escudella d'arròs, cols, la carn d'olla al mig, ab moltó i vaca excel.lent, ab tot lo demés reliquo que hi entra de verdures, botifarra i cansalada. En los intermedis de la simetria quedaven les tallades de meló - dolces com una mel, pués hauria sigut xasco que haguessen estat carabassa- i les salseres ab salsa de tomàtec; oint-se en l'escudella tal sonido de culleres com campanetes de convents de monges en Barcelona, quan toquen a les cinc de la tarda. I llavores tothom callava, i no después de l'escudella i olla, que ja s'hi començava a enraonar, havent-hi ja un poc de fonament a la panxa” 5 .

El segundo servicio reunía un conjunto de segundos platos, básicamente de volatería. Uno de los platos era el típico de melocotones rellenos. Acompañaban algunos platos de capricho, entremeses al estilo francés:

"Desocupada la primera simetria, ha entrat la segona, de relleno de préssecs al mig, ab suc, tot allò ben llépol, per lo dolç; guisado ab ànecs, altre de colomins; alguns orduvres de pèsols $\mathrm{i}$ altres espècies incitatives a l'apetit. D'estos, lo plat de botifarres fresques, vianda fora temps, i algo picantetes; pollastres rostits i tortada d'agredolç, gobelets de llet i crema, tot delicat. I a més, ja no podia passar pel coll, per tenir ja hom lo ventre com un tinter» 53 .

Finalmente cerraba el menú la tercera simetría, con los postres, básicamente de frutas del tiempo:

"Ha seguit la tercera simetria de les postres, de sindria dolça fresca, raims $i$ altres fruits dels temps, finint la bucòlica ab bons tragos de vi de Màlaga, sucant-hi en veires algun secall o melindro. Alegres i satisfets, hem donat gràcies a Déu, com deviem, i nos hem aixecats de la cadira per rentar-

5. Ibidem, vol. III, pág. 134.

Ibidem, vol. III, págs. 134-135.

Ibidem, vol. III, pág. 135. 
nos i eixugar-nos les mans, i glopejar un poc d'aigua los que hi tenen de costum, i pendre-hi un polvo los aficionats" 54 .

Mientras las preferencias del Barón de Maldá, hombre muy conservador, se inclinaban en general por la comida tradicional, las gentes acomodadas que buscaban promocionarse socialmente y hacer ostentación de su riqueza utilizaban la gastronomía francesa como un testimonio más de su éxito y de su modernidad. En plena guerra de la Independencia en 1813, Erasmo de Gónima, ejemplo perfecto de un burgués nuevo rico, ofreció en su casa de Barcelona un gran banquete ${ }^{55}$. El menú es un buen exponente del afrancesamiento de Don Erasmo, al menos en el ámbito culinario. En aquella época el prestigio de la gastronomía francesa se proyectaba en la alta cocina española, transformándola a su imagen y semejanza, independientemente de las convicciones políticas de sus seguidores y de la ocupación del ejército napoleónico. El proveedor fue un francés, Louis Barre, uno de los numerosos cocineros franceses que triunfaban en Barcelona desde finales del siglo XVIII, y el menú, redactado en francés, era también típico de la alta cocina francesa, tanto en sus diferentes apartados clásicos, "orduvres", "entrées", "pieces froides", "rôtis» y "entremets» —en total cinco servicios-, como en los numerosos y variados platos que lo componen. El convite se dio con motivo de la boda del nieto de Don Erasmo, Erasmo Janer Gònima, con Josefa Gironella y asistieron los jefes militares y las más altas autoridades ${ }^{56}$. Su precio total, 1.251 pesetas, era una cifra astronómica para la época, especialmente escandalosa en tiempos de escasez y de hambre para tanta gente.

\begin{tabular}{lc}
\hline \multicolumn{1}{c}{ Banquete del 2 de mayo de 1813} & Piecettes \\
\hline 3 soupes au pain & 7 \\
3 soupes au macaronis & 8 \\
4 bouillis et poules & 100 \\
Orduvres & 15 \\
3 plats de croquettes & 10 \\
3 plats de filéts de poisson en marinade & \\
& \\
& \\
&
\end{tabular}


Banquete del 2 de mayo de 1813

Piecettes

2 aspics

2 plats de friture de cervelles

3 plats de pieds de cochon a la sainte Menoult $\quad 10$

3 plats de cotelettes de veaux en papillote $\quad 10$

3 plats de petits patés

5 plats de cotelettes d'agneau

2 poitrines d'agneau panées a l'anglaise

6 plats d'anchois

1 tête de veau

\section{Entrées}

2 granades de filets de volaille 28

3 bolevents $\quad 28$

3 plats de filets de sole $\quad 30$

2 filets de cochon piqués en turban 30

3 plats de perneaux $\quad 36$

3 plats de fricandeau 30

2 plats de filets de lapin piques et farcis 26

2 popetons de filet de poisson $\quad 20$

2 canards aux trufes $\quad 17$

2 plats de canetons 15

2 plats de poitrine de veau 18

1 entrée de poulardes 18

2 musettes d'agneau $\quad 12$

2 plats de pouléts $\quad 24$

2 plats de pigeons 20

\section{Pieces froides}

1 heure de cochon dorée $\quad 50$

3 poissons garnis 60

1 gateau de lievre $\quad 45$

1 poulet d'inde en galantine $\quad 30$

1 jambon glacé $\quad 30$

1 paté de lievre $\quad 35$

1 paté de perdreaux 40

2 plats de langoutes $\quad 14$

\section{Rôtis}

2 rôtis de cailles

1 rôti de pigeons 18

2 rôtis de veau 24

1 lievre piqué et rôti 11 
Banquete del 2 de mayo de 1813 Piecettes

1 rôti de poulardes 15

1 derriere de agneau 12

1 rôti de perdreaux 20

\section{Entremets}

2 plats de gateau de Savoye

2 plats de nougats 25

3 tourtres a la confiture 20

2 croquantes 16

2 plats de blanc manger 12

3 cremes 18

3 plats de petits pots 10

3 plats de gelée d'oranges 12

3 plats de caisse d'amandes

3 plats de gateau a la Madeleine

3 plats de petits pois

3 plats d'artichaux 8

3 plats de feves 7

3 plats d'epinards 6

6 plats d'asperges

Pour les ports 15

Pour le garçon qui a servi

El banquete se iniciaba con un primer servicio, "a base de sopas y "orduvres", una serie de platos muy variados, tanto de carne como de pescado, pero que a tenor de su precio debían ser pequeños, destinados a servir de aperitivo. Después seguían los entrantes, «entrées», un conjunto igualmente muy variado, volatería, carne, pescado, pero de mayor consistencia, como indica claramente su precio más elevado. A continuación el tercer servicio a base de platos fríos, "pieces froides", era un ejemplo de sofisticación y estaba formado por platos también de carne y de pescado, sobre todo patés, pasteles, gelatinas. Como culminación del banquete se presentaba el tradicional asado, que continuaba ocupando un lugar destacado en el curso del festín y que estaba compuesto sobre todo de volatería refinada, pulardas, perdices, codornices y pichones, y de las mejores carnes, ternera, cordero, y caza, liebre. Al final los postres, tanto salados como dulces. Entre los salados destacan algunas verduras consi- 
deradas especialmente selectas, como guisantes, habas, alcachofas, espinacas y espárragos. Los postres dulces abarcan desde platos muy tradicionales, de origen medieval, como el manjar blanco y los turrones, a dulces de moda como la "gelée" de naranja.

El banquete generó tan grandes expectativas en la época moderna, una época de hambre crónica para tanta gente, que alcanzó a convertirse, en cierto modo, en un ideal de vida, un objetivo a conseguir a ser posible en este mundo, en lugares más próximos o más lejanos, o en último término, si no era posible disfrutarlo en la tierra, al menos en el cielo. El imaginario colectivo soñaba con la tierra de Jauja, tierra de abundancia y de placer, y para los españoles América, el nuevo mundo sobre el que se proyectaron tantos deseos y aspiraciones, se presentó también como Eldorado alimenticio, tal como reflejaba la literatura de la época, por ejemplo La tierra de Jauja de Lope de Rueda de 1547, que identificaba la utopía alimentaria con el Nuevo Mundo ${ }^{57}$. Incluso tenía el banquete un sentido religioso. En las Sagradas Escrituras se hablaba repetidamente del reino de los cielos como de un gran banquete, en el banquete de las bodas de Caná hizo Jesús su primer milagro cambiando el agua en vino, la multiplicación de los panes y los peces era un claro signo de la abundancia de la salvación, la Santa Cena ocupaba un lugar importante en el cristianismo y la Eucaristía en ella fundada daba a comer y beber el cuerpo y la sangre de Cristo, bajo la forma de dos alimentos esenciales en el mundo mediterráneo, el pan y el vino. Todas ellas eran sugerentes referencias alimentarias, a pesar del sentido ascético riguroso que predicaba la Iglesia y de los preceptos de ayuno y abstinencia, tratando de aplazar el disfrute del gran banquete soñado al mundo del más allá, cuando la mayoría de la gente lo que quería era banquetear aquí y ahora, convertir en el presente inmediato la necesidad de comer para vivir en el placer de vivir para comer.

57 Más referencias literarias sobre el tema, FERnANDEZ NIETO, Manuel, "América en la literatura española", en La huella de América en España. Valencia, Generalitat valenciana, 1993. MorıNıGo, Marcos A., América en el teatro de Lope de Vega. Buenos Aires, Instituto de Filología, 1946. Franco, Ángel, El tema de América en los autores del Siglo de Oro. Madrid, 1954. PEDro, Valentín de, América en las letras españolas del Siglo de Oro. Buenos Aires, Ed. Sudaméricana, 1954. 